\title{
Model Assessment of Protective Barrier Designs: Part II
}

M. J. Fayer

November 1987

Prepared for the U.S. Department of Energy under Contract DE-AC06-76RLO 1830

Pacific Northwest Laboratory

Operated for the U.S. Department of Energy

by Battelle Memorial Institute 


\section{DISCLAIMER}

This report was prepared as an account of work sponsored by an agency of the United States Government. Neither the United States Government nor any agency thereof, nor Battelle Memorial Institute, nor any of their employees, makes any warranty, expressed or implied, or assumes any legal liability or responsibility for the accuracy, completeness, or usefulness of any information, apparatus, product, or process disclosed, or represents that its use would not infringe privately owned rights. Reference herein to any specific commercial product, process, or service by trade name, trademark, manufacturer, or otherwise, does not necessarily constitute or imply its endorsement, recommendation, or favoring by the United States Government of any agency thereof, or Battelle Memorial Institute. The views and opinions of authors expressed herein do not necessarly state or reflect those of the United States Government or any agency thereof, or Battelle Memorial Institute.

\section{PACIFIC NORTHWEST LABORATORY operated by \\ BATTELLE MEMORIAL INSTITUTE for the UNITED STATES DEPARTMENT OF ENERGY under Contract DE-ACO6-76RLO 1830}

\begin{tabular}{c} 
Printed in the United States of America \\
Available from \\
National Technical Information Service \\
United States Department of Commerce \\
5285 Port Royal Road \\
Springfield, Virginia 22161 \\
NTIS Price Codes \\
Microfiche A01 \\
Printed Copy \\
Pages \\
\hline $001-025$ \\
$026-050$
\end{tabular}


PNL-6297

UC -70

MODEL ASSESSMENT OF PROTECTIVE

BARRIER DESIGNS: PART II

M. J. Fayer

November 1937

Prepared for

the U.S. Department of Energy

under Contract DE-ACO6-76RLO 1830

Pacific Northwest Laboratory

Richland, Washington 99352 


\section{PREFACE}

Protective barriers are being considered for use at the Hanford Site to enhance the isolation of radioactive wastes from water, plant, and animal intrusion. This study is part of an ongoing effort to assess the effectiveness of protective barriers for isolation of wastes from water. Part I of this study was the original modeling assessment by Pacific Northwest Laboratory of various protective barrier designs (e.g., soil type, vegetation). In this companion report (Part II), additional barrier designs are reviewed and several barrier modeling assumptions are tested. 



\section{ACKNOWLEDGMENTS}

This study was supported by the U.S. Department of Energy's Hanford Defense Waste Protective Barriers Program. Dick Wing, Dennis Myers, and Steve Phillips of Westinghouse Hanford Company are acknowledged for their helpful criticisms and suggestions. Special thanks are due to personnel at Pacific Northwest Laboratory: Glendon Gee for his helpful suggestions and support, Bill Conbere for his peer review, Mindy Strong for editing an early draft, Steve Weiss for editing the final draft, and Chris Morgan for word processing when I really needed it. 


\section{SUMMARY}

In 1986, Pacific Northwest Laboratory conducted computer model simulations of the water dynamics of the type of protective barrier that is planned for use at the Hanford Site for waste isolation. The purposes of the simulations were to provide information to the Hanford Site operations contractor for improving the conceptual design of the barrier and to test several barrier modeling assumptions.

The one-dimensional flow code UNSAT-H was used to study drainage through the barrier. The variables studied included soil thickness, an intermediate sand layer, reduced plant activity, revised soil hydraulic properties, and historical weather data. The two-dimensional flow code UNSAT2 was used to study subbarrier flow. The variables studied were soil type, recharge rate, distance between waste and barrier edge, and soil layering.

Under the test conditions, the one-dimensional simulations revealed several characteristics of the barrier. First, the thickness of soil (with no plants) required to minimize drainage was dependent on soil texture. Coarse-textured soils performed better (minimized drainage) at thicknesses less than $1.5 \mathrm{~m}$. Second, a sand layer between the gravel and fine soil resulted in an increase in drainage of about $0.1 \mathrm{~cm} / \mathrm{yr}$. When absolute estimates of drainage are required, such intermediate layers should be included in the conceptual model of the barrier. Third, reduced cheatgrass activity on the barrier led to drainage of $0.4 \mathrm{~cm} / \mathrm{yr}$ under an annual precipitation regime of $30.1 \mathrm{~cm} / \mathrm{yr}$. This result indicates that there is a minimum plant presence required for the barrier to prevent drainage. Fourth, the amount of drainage through the barrier was shown to be sensitive to the hydraulic properties of the fine-textured soil layer, thus indicating the need for detailed characterization of soil used in the barrier. Finally, the use of historical yearly precipitation distributions resulted in simulated drainage increases of 50 to $100 \%$ above the drainage pre. dicted using an average yearly precipitation distribution, indicating the need to use the historical data in future simulations.

The two-dimensional simulations resulted in three conclusions about subbarrier flow. First, the hydraulic properties of the material surrounding the waste indicated how far the barrier edge should be from the waste, i.e., the 
finer-textured the soil is, the farther the waste should be from the edge. Second, fluxes past waste that was surrounded by sandy soil were less than $0.1 \mathrm{~cm} / \mathrm{yr}$ after only 50 years, assuming no drainage through the barrier. This finding held true for recharge rates of 0.5 and $5.0 \mathrm{~cm} / \mathrm{yr}$ beyond the barrier edge. Therefore, a drainage rate through the barrier as low as $0.1 \mathrm{~cm} / \mathrm{yr}$ would tend to dominate the flow regime around the waste, regardless of flow from beyond the barrier edge. Finally, natural soil layering beyond the barrier was shown to have little effect on flow past the waste, provided the waste was surrounded by AP1 soil material. 


\section{CONTENTS}

PREFACE $\ldots \ldots \ldots \ldots \ldots \ldots \ldots \ldots \ldots \ldots \ldots \ldots \ldots \ldots \ldots \ldots \ldots \ldots \ldots \ldots \ldots \ldots \ldots \ldots \ldots \ldots$

ACKNOWLEDGMENTS $\ldots \ldots \ldots \ldots \ldots \ldots \ldots \ldots \ldots \ldots \ldots \ldots \ldots \ldots \ldots \ldots$

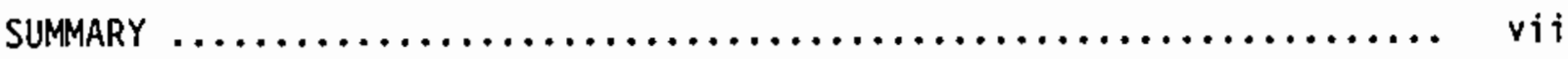

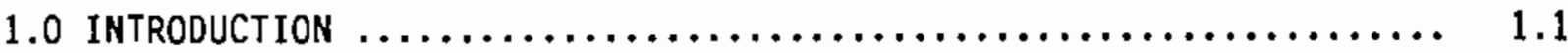

2.0 DESCRIPTION OF ONE-DIMENSIONAL SIMULATIONS $\ldots \ldots \ldots \ldots \ldots \ldots \ldots \ldots$

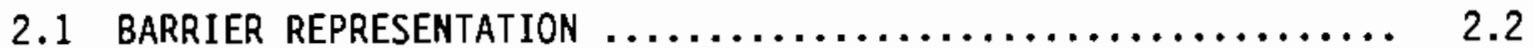

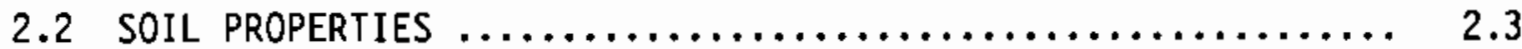

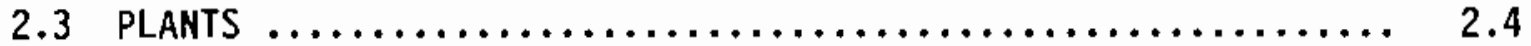

2.4 INITIAL CONDITIONS $\ldots \ldots \ldots \ldots \ldots \ldots \ldots \ldots \ldots \ldots \ldots \ldots \ldots \ldots \ldots \ldots$

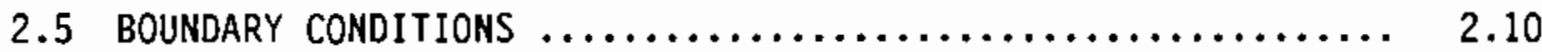

3.0 RESULTS OF ONE-DIMENSIONAL SIMULATIONS $\ldots \ldots \ldots \ldots \ldots \ldots \ldots \ldots \ldots \ldots .1$

3.1 SOIL LAYER THICKNESS $\ldots \ldots \ldots \ldots \ldots \ldots \ldots \ldots \ldots \ldots \ldots \ldots \ldots \ldots \ldots \ldots \ldots \ldots \ldots$

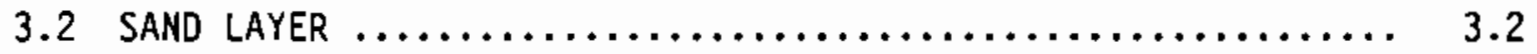

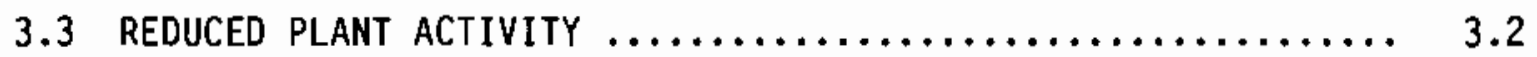

3.4 REVISED SOIL HYDRAULIC PROPERTIES $\ldots \ldots \ldots \ldots \ldots \ldots \ldots \ldots \ldots \ldots \ldots$

3.5 HISTORICAL WEATHER RECORD $\ldots \ldots \ldots \ldots \ldots \ldots \ldots \ldots \ldots \ldots \ldots \ldots \ldots \ldots \ldots \ldots$

4.0 DESCRIPTION OF TWO-DIMENSIONAL SIMULATIONS $\ldots \ldots \ldots \ldots \ldots \ldots \ldots \ldots . .1$

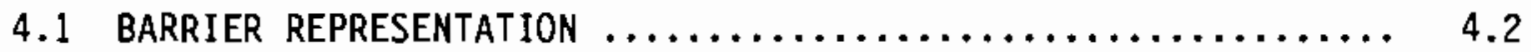

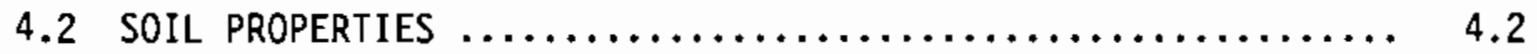

4.3 INITIAL CONDITIONS $\ldots \ldots \ldots \ldots \ldots \ldots \ldots \ldots \ldots \ldots \ldots \ldots \ldots \ldots \ldots \ldots$

4.4 BOUNDARY CONDITIONS $\ldots \ldots \ldots \ldots \ldots \ldots \ldots \ldots \ldots \ldots \ldots \ldots \ldots \ldots \ldots \ldots \ldots$

5.0 RESULTS OF TWO-DIMENSIONAL SIMULATIONS $\ldots \ldots \ldots \ldots \ldots \ldots \ldots \ldots \ldots \ldots$

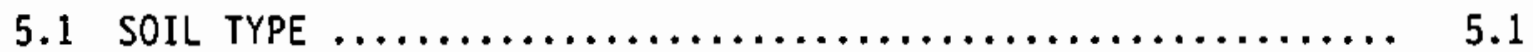

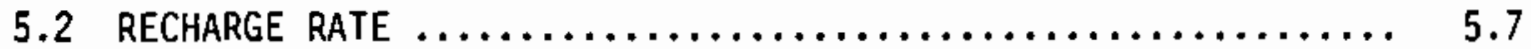

5.3 Distance BETWEEN WASTE AND BARRIER EDGE $\ldots \ldots \ldots \ldots \ldots \ldots \ldots \ldots .7$ 


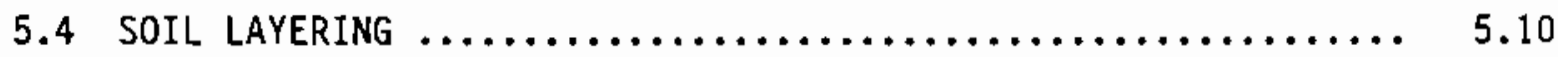

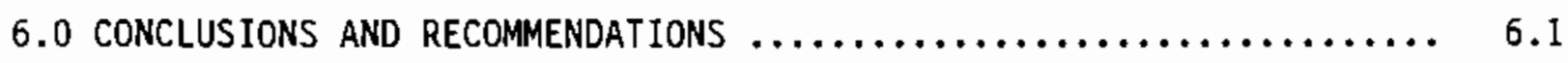

6.1 CONCLUSIONS $\ldots \ldots \ldots \ldots \ldots \ldots \ldots \ldots \ldots \ldots \ldots \ldots \ldots \ldots \ldots \ldots \ldots, 6.1$

6.2 RECOMMENDATIONS $\ldots \ldots \ldots \ldots \ldots \ldots \ldots \ldots \ldots \ldots \ldots \ldots \ldots \ldots \ldots, 6.2$

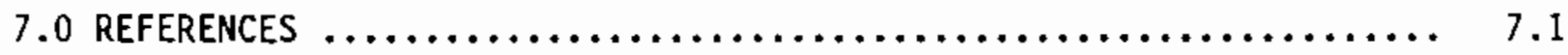




\section{FIGURES}

2.1 Moisture Characteristics and Hydraulic Conductivity Functions of Barrier Materials ............................... 2.5

2.2 Moisture Characteristics and Hydraulic Conductivity Functions for RN2 Sol1 of 1985 and the Revised RN2 Sol1 of $1986 \ldots \ldots \ldots \ldots .2 .6$

2.3 Annual Variation in Potential Transpiration of Cheatgrass as a

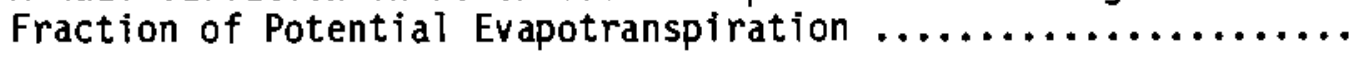

2.4 Annual Variation in Maximum Rooting Depth of Cheatgrass ....... 2.9

4.1 Barrier Conceptualization for Two-Dimensional Modeling ........ 4.3

4.2 Finite Element Grid for the Majority of Two-Dimensional

4.3 Finite Element Grid for Two-Dimensional Simulation of Barrier with Fine-Textured Soil Layer Between 62- and

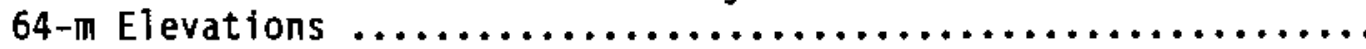

4.4 Moisture Characteristics and Hydraulic Conductivity Functions of Materials Used in Two-Dimensional Simulations

5.1 Simulated Total Head and Moisture Content Contours for

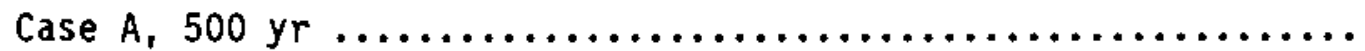

5.2 Simulated Total Head and Moisture Content Contours for

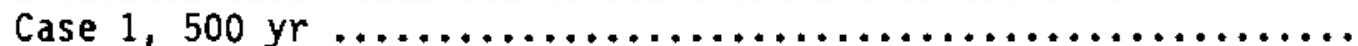

5.3 Simulated Total Head and Moisture Content Contours for

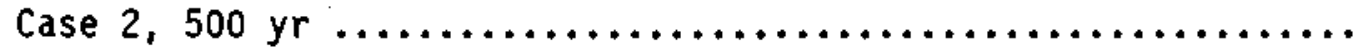

5.4 Estimated Flux Past Bottom-Left Corner of Waste Tank Versus

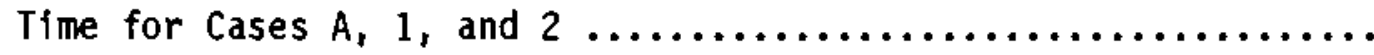

5.5 Simulated Total Head and Moisture Content Contours for Case 3,500 yr ...................................

5.6 Simulated Total Head and Moisture Content Contours for

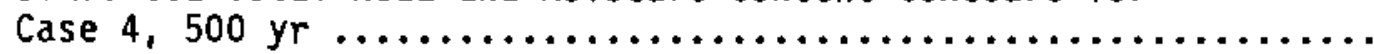

5.7 Estimated Flux Past Bottom-Left Corner of Waste Tank Versus

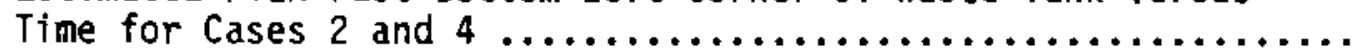

5.8 Simulated Total Head and Moisture Content Contours for

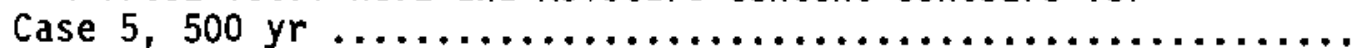




\section{$\underline{\text { TABLES }}$}

2.1 Simulation Node Depths for a Barrier Designed with a 150-cm-Thick Fine-Textured Soil Layer ..................... 2.3

3.1 Simulated Annual Drainage as a Function of Soil Thickness ...... 3.1

3.2 Simulated Annual Drainage When a Coarse Sand Layer is Present Between the Depths of 150 and $190 \mathrm{~cm} \ldots \ldots \ldots \ldots \ldots \ldots \ldots \ldots \ldots \ldots \ldots .2$

3.3 Simulated Annual Drainage Using the Revised Soil Hydraulic Properties for the RN2 Soil $\ldots \ldots \ldots \ldots \ldots \ldots \ldots \ldots \ldots \ldots \ldots \ldots \ldots \ldots \ldots . .3$

3.4 Simulated Annual Drainage for 25 Years of Hanford Weather

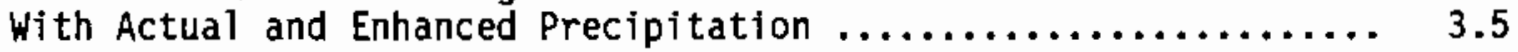

5.1 Summary of Two-Dimensional Simulation Variables $\ldots \ldots \ldots \ldots \ldots \ldots . .2$ 


\subsection{INTRODUCTION}

Radioactive waste exists at the Hanford Site in a variety of locations, including subsurface tank farms, solid waste burial grounds, and contaminated soil sites. Some of these waste sites may need to be isolated from flowing water to minimize the potential for transport of the waste to the groundwater, which eventually discharges to the Columbia River. Multilayer "protective barriers" have been proposed as a means of limiting the flow of water through the waste sites (U.S. Department of Energy 1986). A multiyear research program, managed first by Rockwell Hanford Operations and now by Westinghouse Hanford Company, is aimed at assessing the performance of these barriers (Adams and Wing 1987). One aspect of this program involves the use of computer models to predict barrier performance. Two modeling studies have already been conducted (Lu, Phillips, and Adams 1982; Fayer et al. 1985). The simulation work reported here was conducted by Pacific Northwest Laboratory and extends the work of Fayer et al. (1985).

The purposes of this report are to provide information that can be used to improve the conceptual design of the protective barrier and to test several barrier modeling assumptions. The results should be viewed as useful for decision making during barrier design development, but not as representative of the performance of the final, optimally designed barrier.

The two aspects of the protective barrier that were studied are 1) drainage through the barrier and 2) subbarrier flow that originates beyond the edge of the barrier. In the first case, the one-dimensional flow code UNSAT-H (Fayer, Gee, and Jones 1986) was used to study the ability of the barrier to limit drainage. The five specific items studied are 1) soil thicknesses less than $1.5 \mathrm{~m}$, 2) the presence of a sand layer at the $1.5-\mathrm{m}$ depth, 3) the use of plant parameters that represent reduced plant activity, 4) revised hydraulic properties for the fine-textured soit, and 5) the use of historical Hanford weather data as opposed to using average weather data.

The second aspect of the protective barrier, subbarrier flow, was studied using the two-dimensional code UNSAT2 (Davis and Neuman 1983). The specific items studied are 1) soil type, 2) recharge rate outside the barrier, 3) distance between the waste and the barrier edge, and 4) soil layering. 


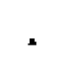




\subsection{DESCRIPTION OF ONE-DIMENSIONAL SIMULATIONS}

The one-dimensional simulations reported here are an extension of work started in 1985 (Fayer et al. 1985). In all cases, mass balance errors generated by UNSAT-H were less than $0.1 \mathrm{~cm} / \mathrm{yr}$. Therefore, water balance values (e.g., drainage) are reported to the nearest $0.1 \mathrm{~cm}$. Where drainage was less than $0.1 \mathrm{~cm} / \mathrm{yr}$, it was reported as such. Sometimes a simulation indicated that the drainage rate may eventually be zero if carried forward in time. In this situation, the reported drainage value is enclosed in parentheses. This method of reporting drainage differs from that used in 1985, when drainage less than $0.1 \mathrm{~cm} / \mathrm{yr}$ was reported as zero. For purposes of barrier design comparison and model assumption testing, the distinction between " $<0.1 \mathrm{~cm} / \mathrm{yr}$ " and "zero" may not be critical. The distinction does become important, however, when the reported value of "zero" is interpreted as an absolute estimate of drainage.

Five areas concerning barrier design or modeling assumptions are examined in this report. These areas are 1) soil layer thickness, 2) sand layer, 3) reduced plant activity, 4) revised soil hydraulic properties, and 5) historical weather data.

The reference barrier design suggested in the Draft Environmental Impact Statement for Hanford Site Defense Wastes (U.S. Department of Energy 1986) calls for a $150-\mathrm{cm}$ depth of fine-textured soil. In that document, simulations indicated that increased soil thickness $(300 \mathrm{~cm})$ resulted in increased drainage for the soil studied, a soil which was similar to the Ritzville soil used in the 1985 study. Not explored was the prospect that a layer of soil thinner than $150 \mathrm{~cm}$ may decrease drainage. In this report, simulations were conducted with soil layer thicknesses of 75,105 , and $135 \mathrm{~cm}$ for two different soil types.

Another aspect of the barrier design not in the 1985 analysis but included here is the use of an intermediate-textured material, such as a coarse sand, between the fine soil layer and the underlying gravel. The sand layer minimizes the amount of soil sifting into the gravel, thus maintaining the integrity of the textural break. A more gradual transition from soil to gravel encourages drainage. Therefore, it was expected that including a coarse sand layer in 
the barrier model design would decrease the modeled barrier performance (increase drainage), although by how much remained to be seen.

Following the 1985 report, the plant parameters used in the simulations were re-examined and a more realistic portrayal of plant activity, reduced relative to the 1985 study, was established. A simulation with RN1 soil (described in Section 2.2), no surface gravel, and $30.1 \mathrm{~cm} / \mathrm{yr}$ precipitation was performed to see if the barrier with the reduced plant activity would minimize drainage as well as the comparable barrier simulation in the 1985 study.

The 1985 report has soil hydraulic property data for the Composite soil (described in Section 2.2). These data consist of pressure plate measurements at $102,306,1020,3060$, and $15,300 \mathrm{~cm}$ of suction head. For the report, polynomials were fitted to the data to provide a continuous representation of moisture retention at all values of suction head. On conducting the simulations, Fayer et al. (1985) discovered that suction heads within draining barriers varied between 0 and $100 \mathrm{~cm}$ in the lower $50 \mathrm{~cm}$ of soil, just above the soil-gravel interface. They reasoned that because this range in suction was so prevalent, better hydraulic property characterization was warranted in this range of suction. Two of the 1985 scenarios were resimulated in 1986 with the revised soil properties.

The last area explored in this report is the assumption underlying the use of the "average rain year," that assumption being that there is no loss of accuracy in replacing the real sequence of annual weather data with averaged data, which is then repeated for the required number of years. To test the validity of this assumption, a 25-year record of Hanford weather data was assembled and used in two simulation exercises.

\subsection{BARRIER REPRESENTATION}

In general, the conceptual design of the barrier is the same as that used in 1985, except for slight differences in nodal depths. For this report, node depths for the majority of the simulations are shown in Table 2.1. In the cases where the soil layer thickness was reduced, the nodal spacing was, of necessity, changed. Although not reported here, the nodal depths for such 
TABLE 2.1. Simulation Node Oepths for a Barrier Designed with a 150-cm-Thick Fine-Textured Soil Layer

\begin{tabular}{rccccccc}
$\begin{array}{c}\text { Node } \\
\text { No. }\end{array}$ & $\begin{array}{c}\text { Oepth } \\
(\mathrm{cm})\end{array}$ & $\begin{array}{c}\text { Node } \\
\text { No. }\end{array}$ & $\begin{array}{c}\text { Depth } \\
(\mathrm{cm})\end{array}$ & $\begin{array}{r}\text { Node } \\
\text { No. }\end{array}$ & $\begin{array}{r}\text { Oepth } \\
(\mathrm{cm})\end{array}$ & $\begin{array}{r}\text { Node } \\
\text { No. }\end{array}$ & $\begin{array}{r}\text { Oepth } \\
(\mathrm{cm})\end{array}$ \\
\hline 1 & 0.0 & 11 & 28.0 & 20 & 100.0 & 29 & 153.0 \\
2 & 0.1 & 12 & 32.0 & 21 & 110.0 & 30 & 157.0 \\
3 & 0.2 & 13 & 36.0 & 22 & 120.0 & 31 & 165.0 \\
4 & 0.5 & 14 & 44.0 & 23 & 130.0 & 32 & 181.0 \\
5 & 1.0 & 15 & 52.0 & 24 & 138.0 & 33 & 220.0 \\
6 & 2.0 & 16 & 60.0 & 25 & 143.0 & 34 & 280.0 \\
7 & 4.0 & 17 & 70.0 & 26 & 147.0 & 35 & 340.0 \\
8 & 8.0 & 18 & 80.0 & 27 & 149.0 & 36 & 440.0 \\
9 & 16.0 & 19 & 90.0 & 28 & 151.0 & 37 & 540.0 \\
10 & 24.0 & & & & & &
\end{tabular}

simulations are similar to those shown in Table 2.1, except that the increased density of nodes at the $150-\mathrm{cm}$ depth was shifted to the position of the soilgravel interface. In the case of the sand layer simulation, more nodes were added between the depths of 150 and $250 \mathrm{~cm}$ to provide a higher density with in and below the sand layer.

\subsection{SO1L PROPERT1ES}

In 1985, three soils were tested as the fine soil material: the Composite, the Coarse, and the Ritzville silt loam. The Composite soil was a mixture of eight samples taken from a site near the 200-West Area. The Coarse soit represented one of the eight samples. The label "Coarse" indicated that it was the coarsest of the eight samples, but it was not coarse in the formal sense of soil texture classification. To avoid confusion, the Coarse soil will be referred to as the RN1 soil and the Composite as the RN2 soil. Particle size data for these soils can be found in Appendix A of Fayer et al. (1985).

The barrier materials used in most of the one-dimensional simulations in this report are RN2 soil mixed with pea gravel (15\% by weight) for the top $30 \mathrm{~cm}$ of the barrier, RN2 soil for the next $120 \mathrm{~cm}$, and gravel $(0.6-1.3 \mathrm{~cm}$ dia) for the bottom $390 \mathrm{~cm}$. The moisture characteristics and hydraulic conductivity functions of the RN2 soil-gravel mix and the gravel are illustrated 
in Figure 2.1 (properties for the RN2 soil can be found in Figure 2.2). For the plant simulation, the RN1 soil (without gravel) was used for the upper $150 \mathrm{~cm}$, and its properties are also illustrated in Figure 2.1. The RN1 soil was chosen for this test because it showed the greatest likelihood of drainage for all of the 1985 plant simulations.

For two simulations, a coarse sand layer was included between the 150 and $190 \mathrm{~cm}$ depths. Moisture retention data for a coarse sand were obtained from Gee and Simmons (1979), and a hydraulic conductivity function was generated using the Millington-Quirk method (Bond, Cole, and Gutknecht 1984). The measured and calculated properties of the coarse sand (hereafter called CSAND) are included in Figure 2.1. Although there are no particle size data for CSAND, we estimated the particle size range to be 0.5 to 1.0 man dia.

One of the recommendations of the 1985 study was to characterize the moisture characteristic in more detail in the 0 - to $100-\mathrm{cm}$ range of suction head. This recommendation was followed for the RN2 soil without gravel. Displayed in Figure 2.2a are the moisture retention data collected from two samples of RN2 soil during a hanging water column experiment (for the technique, see Vomocil 1965). The polynomial fit of the revised RN2 data is shown in Figure $2.2 \mathrm{a}$, along with the polynomial fit used in the 1985 study. Note that water retention of the revised RN2 soil is much higher than that of the 1985 RN2 soil. The effect of the changed moisture characteristic is carried over into the estimate of the hydraulic conductivity function (Figure 2.2b). At suction heads above $10 \mathrm{~cm}$, the revised RN2 soil has conductivity values that are an order of magnitude higher than those of the 1985 RN2 soil.

\subsection{PLANTS}

Plant modeling in the UNSAT-H model is based on the potential evapotranspiration (PET) concept. In this concept, evapotranspiration at a given site is equivalent to PET, as calculated from surface and climatological data, provided the water supply is not limiting. Under water-limiting conditions, poten= tial transpiration (PT) is some fraction (C) of PET, such that PT $=C \times$ PET. The fraction $C$ depends on the time of year and the composition of the plant community. 

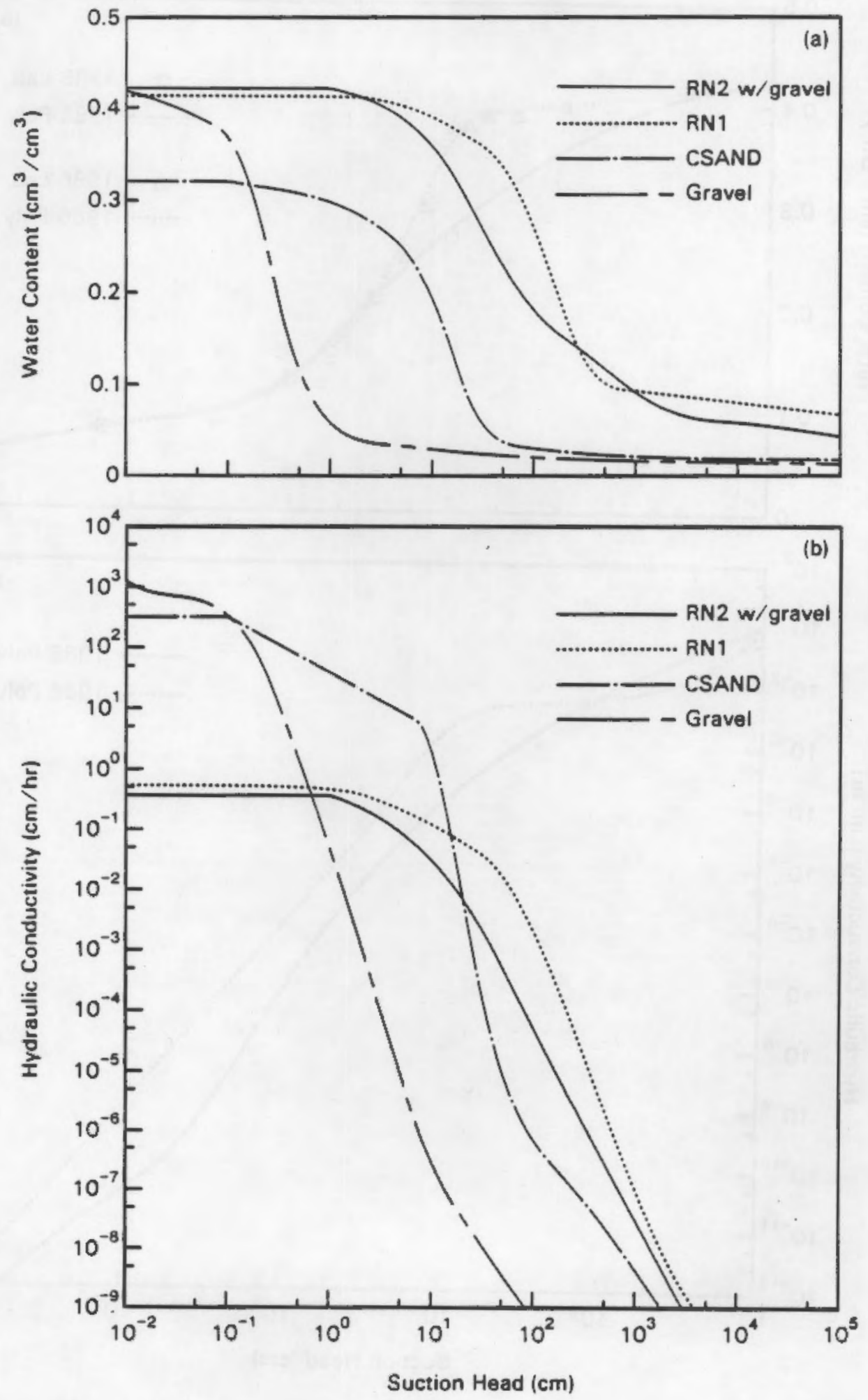

FIGURE 2.1. Moisture Characteristics (a) and Hydraulic Conductivity Functions (b) of Barrier Materials 

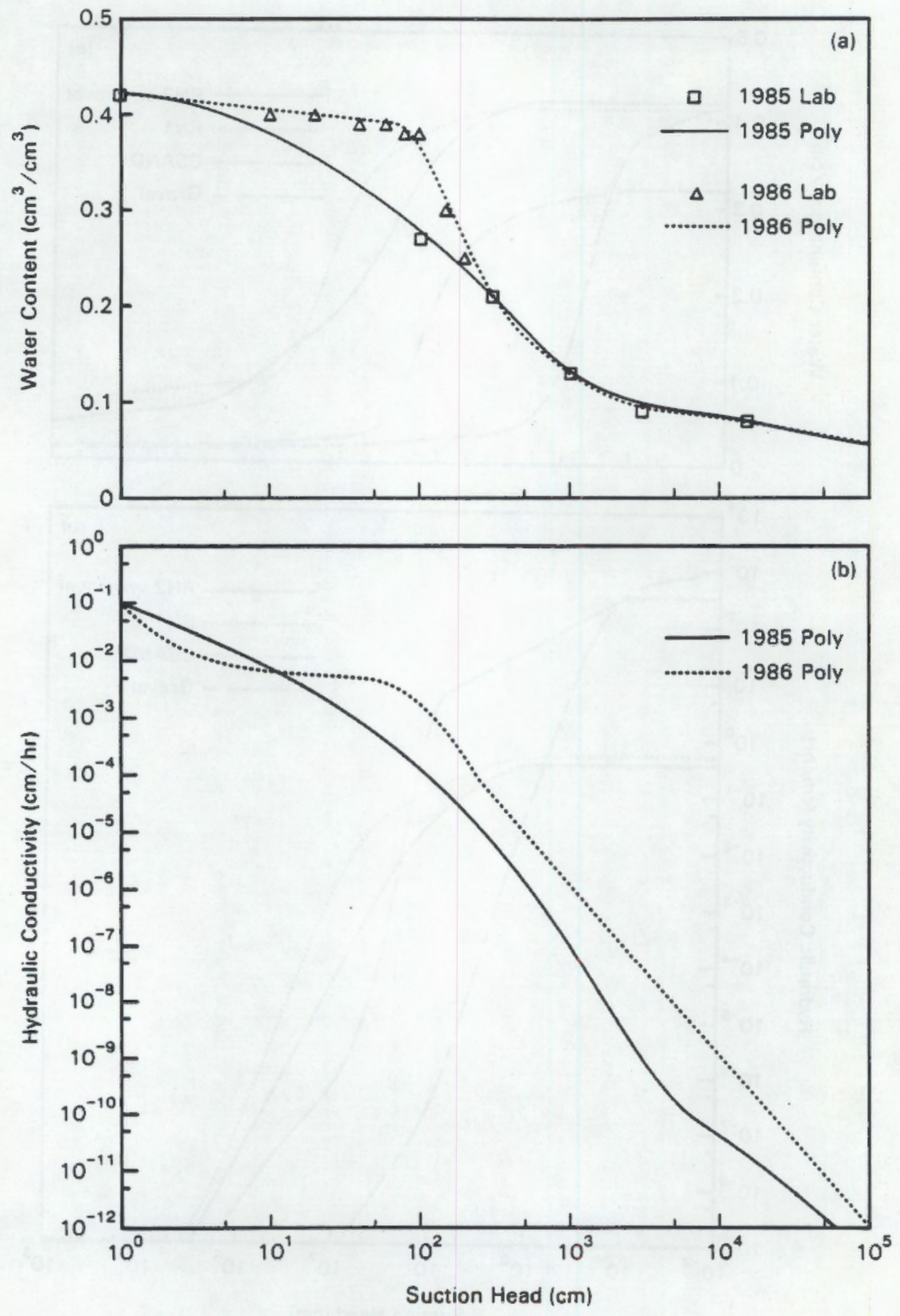

FIGURE 2.2. Moisture Characteristics (a) and Hydraulic Conductivity Functions (b) for RN2 Soil of 1985 and the Revised RN2 Soil of 1986 


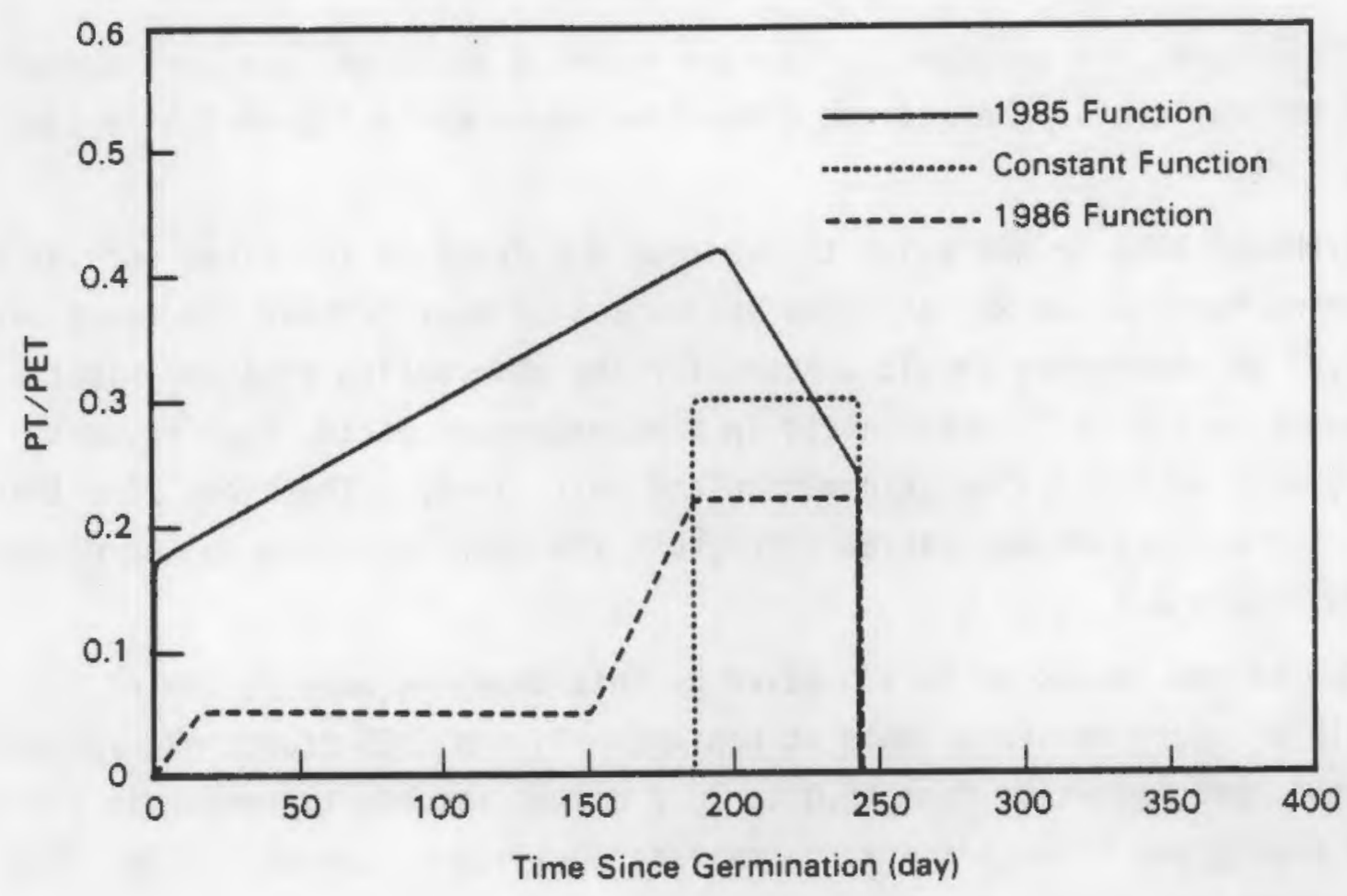

FIGURE 2.3. Annual Variation in Potential Transpiration (PT) of Cheatgrass as a Fraction of Potential Evapotranspiration (PET)

Hinds (1975) collected evapotranspiration data for Bromus tectorum (cheatgrass) growing at the Hanford Site during a 2-month period in 1972. Based on some of the Hinds data, a relationship was developed to describe the annual variation in the $C$ fraction. The solid line in Figure 2.3 is the $C$ function used for the 1985 modeling study in which germination was selected to occur on october 1. According to Fayer, Gee, and Jones (1986), the Hinds evapotranspiration data can only be interpreted to give a constant $C$ fraction over the 2-month experimental period, which was March 31 to May 31 . The constant $C$ function is represented by the dotted line from day 182 to day 243 in Figure 2.3 .

The $C$ fraction reported in Fayer, Gee, and Jones (1986) and the 1985 modeling study was actually the ratio of evapotranspiration to net radiation. Because UNSAT-H operates on PET and not net radiation, the $C$ fraction has been recalculated. Data from the Hanford Meteorological Station for the period of the Hinds experiment indicate that net radiation accounted for only $73 \%$ of 
PET. Therefore, the constant $C$ fraction reported by Fayer, Gee, and Jones should be $27 \%$ lower. The reduced $C$ fraction shows up in Figure 2.3 as the dashed line.

Although data do not exist to describe a $C$ fraction for times outside of the period March 31 to May 31, some approximation must be made. A realistic portrayal of cheatgrass should account for the observation that the plant germinates in the fall, overwinters in a near-dormant state, then resumes major growth in the spring (Klemmedson and Smith 1964). Therefore, for this study, the $C$ fraction was varied throughout the year according to the dashed line in Figure 2.3.

One of the issues to be addressed by this modeling work is the effect of a possible future wetter climate at Hanford. In the 1985 study, nearly doubling the annual precipitation from 16.0 to $30.1 \mathrm{~cm}$ was assumed to result in a doubling of cheatgrass biomass and a concomitant doubling of transpiration. The same assumption is used in this work.

Once UNSAT-H determines the transpirational demand, the demand must be distributed over the root zone. This distribution is accomplished in the UNSAT-H model using the plant root distribution. The root distribution used in this report is the same root distribution used in 1985 [i.e., the cheatgrass root biomass distribution reported by Cline, Uresk, and Rickard (1977) for the end of the growing season]. The maximum rooting depth information used in 1985 is shown in Figure 2.4. Harris (1967) tracked the maximum depth of cheatgrass root penetration in a silt loam soil throughout a growing season. The trace of Harris' data (dashed line in Figure 2.4) through time resembles the relationship used for the dry year scenario in 1985, although Harris' data indicate shallower roots in winter and deeper roots in spring. Harris (1967) conducted his experiments in a silt loam soil, which is finer than the RN2 soil. The area in which the experiments were performed, Pullman, Washington, receives 25 to $45 \mathrm{~cm} / \mathrm{yr}$ of precipitation as opposed to $16 \mathrm{~cm} / \mathrm{yr}$ at the Hanford Site. Because this is the only data set for maximum rooting depth versus time, and because the data were generated under a precipitation climate similar to the wet year scenario, the data were used for the plant modeling contained in this report. 


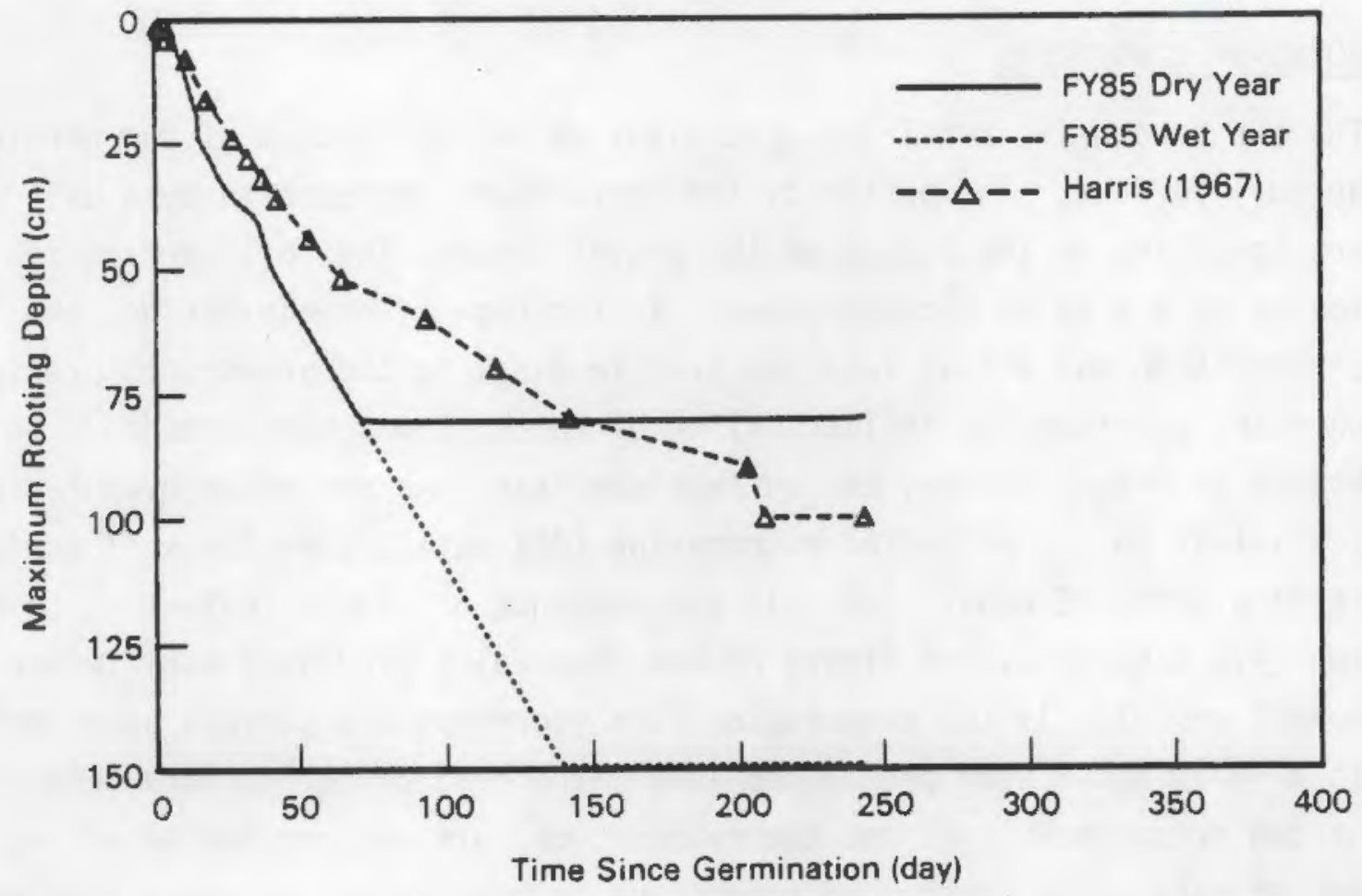

FIGURE 2.4. Annual Variation in Maximum Rooting Depth of Cheatgrass

One final piece of rooting information is the soil suction head (HW), above which plants cannot extract water. In the 1985 study, the value of HW was $15,000 \mathrm{~cm}$. There is indirect evidence in Sauer, Warner, and Hinds (1984) that suggests $\mathrm{HW}$ may be as high as 20,000 to $50,000 \mathrm{~cm}$. For this reason, HW was set to $20,000 \mathrm{~cm}$.

\subsection{INITIAL CONDITIONS}

Whenever a simulation was run with the "average rain year" until equilibrium was reached, the initial conditions were considered unimportant and were not noted. For the situation inyolving the historical Hanford weather data, the year 1961 was simulated repeatedly until the results equilibrated. Each successive year was then simulated using the head conditions at the end of the previous year as the initial conditions. 


\subsection{BOUNDARY CONDITIONS}

The two boundaries requiring specification are the bottom of the barrier and the soil surface. The bottom of the barrier was represented by a unit gradient condition at the bottom of the gravel layer. The soil surface is represented by a flux or constant head. In the case of precipitation, the surface condition was a flux into the profile equal to the prescribed precipitation rate, provided the infiltrability of the soil was not exceeded. In the absence of precipitation, the surface condition was one of an evaporation flux equivalent to the potential evaporation (PE) rate. When the soil surface is bare of plants, PE equals PET. In the presence of plants, potential transpiration (PT) was calculated first; PE was then calculated as the difference between PET and PT. If the evaporation rate increased the surface node suction head to a value above some prescribed level, the head of the surface node was held at the prescribed level and the evaporation rate was recomputed at less than the PE rate. The prescribed upper suction head value for these simulations was $1 \mathrm{million} \mathrm{cm}$.

The source of the weather data was the Hanford Meteorological Station, and summaries can be found in Stone et a1. (1983). The hourly meteorological data were reduced to daily mean values, which were then converted to daily PET values using the Penman Equation in Doorenbos and Pruitt (1977). The precipitation data were hourly and were entered into the simulations as such (snow was treated as an equivalent rainfal1).

In the 1985 study, an "average" rain year (i.e., an average annual precipitation distribution) was used. The annual amount of precipitation was either $16.0 \mathrm{~cm}$, which was called the "dry" year and is the norm for Hanford, or $30.1 \mathrm{~cm}$, which was called the "wet" year. The same "dry" and "wet" years were used for most of the one-dimensional simulations in this study. In one particular case, however, the actual precipitation data for the years 1961 to 1985 were used instead of the "average" rain year. 


\subsection{RESULTS OF ONE-DIMENSIONAL SIMULATIONS}

The goal of the one-dimensional simulations was to examine barrier designs and modeling assumptions. In all studies except those involving historical weather data, the simulations were repeated until there was no change in storage from year to year. In the historical climate simulations, each year was simulated only once. In all cases, UNSAT-H mass balance errors were less than $0.1 \mathrm{~cm} / \mathrm{yr}$.

Throughout the following discussion, frequent mention is given to barrier performance. In this context, barrier performance is equated with drainage through the barrier such that the statement "improved barrier performance" is the same as "reduced drainage."

\subsection{SOIL LAYER THICKNESS}

Drainage results for soil layers of various thicknesses are presented in Table 3.1. For the RN1 soil (without grave1), decreasing the thickness from 150 to $105 \mathrm{~cm}$ reduced drainage to $(\langle 0.1) \mathrm{cm} / \mathrm{yr}$. Reducing the thickness further, to $75 \mathrm{~cm}$, did not compromise the barrier performance, as drainage was still $(<0.1) \mathrm{cm} / \mathrm{yr}$ under the wet year scenario. Continued reduction of the thickness would eventually lead to drainage. Given that there is a range of RN1 soil thicknesses that results in minimal drainage, it would be preferable to choose the greatest thickness as insurance against the possibility of precipitation in excess of $30.1 \mathrm{~cm} / \mathrm{yr}$.

In contrast to the RN1 soil, reducing the thickness of the RN2 soil (with gravel) resulted in only a minimal reduction in drainage. Changing the

TABLE 3.1. Simulated Annual Drainage as a Function of Soil Thickness (30.1 cm/yr precipitation, no plants)

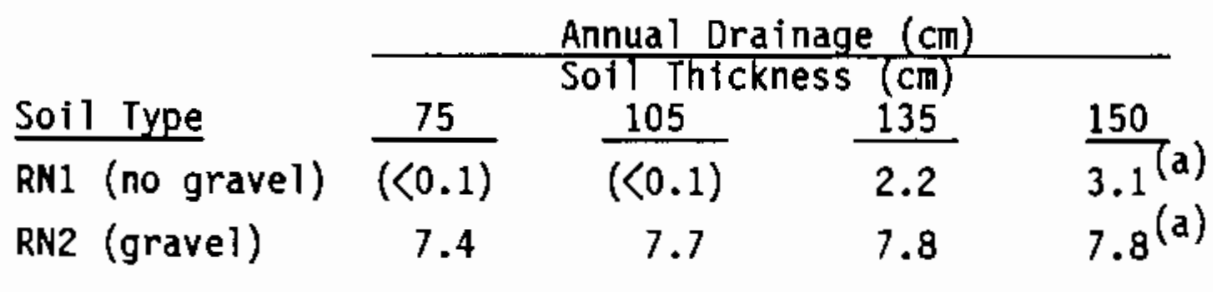

(a) Indicates results from 1985 study. 
RN2 thickness from 150 to $75 \mathrm{~cm}$ yielded a decrease in annual drainage of only $0.4 \mathrm{~cm}$, which is small compared to the total drainage amount of $7.4 \mathrm{~cm}$.

\subsection{SAND LAYER}

As shown by the drainage results presented in Table 3.2, the presence of a sand layer between the fine soil and gravel layers had only a small effect on drainage. Orainage increased by only $0.1 \mathrm{~cm}$ during the dry year and by less than $0.1 \mathrm{~cm}$ during the wet year. The textural break between the fine soil and sand layers was sufficient to limit drainage to the levels expected in the absence of the sand layer. Most comparative modeling work can continue to view the barrier system as just two-layered (soil and gravel). When absolute drainge estimates are required, however, the sand layer, as well as any other materials that may be used in the barrier, should be included in the modeling design. This requirement is especially critical if absolute drainage estimates on the order of $0.1 \mathrm{~cm} / \mathrm{yr}$ are needed.

\subsection{REDUCED PLANT ACTIVITY}

Fayer et a1. (1985) reported that in every barrier scenario involving plants, drainage was reduced to zero. For this report, the available cheatgrass data were re-examined to provide a more realistic portrayal of plant behavior. The 1985 case involving RN1 soll, no surface gravel, and $30.1 \mathrm{~cm} / \mathrm{yr}$ precipitation was chosen to be resimulated because it appeared to be the most likely of the 1985 cases with plants to lead to drainage (based on simulated suction head values at the soll-gravel interface). Repeating

IABLE 3.2. Simulated Annual Drainage When a Coarse Sand Layer is Present Between the Depths of 150 and $190 \mathrm{~cm}$ (RN2 soil with gravelled surface, no plants)

\begin{tabular}{|c|c|c|}
\hline \multirow[b]{2}{*}{$\begin{array}{l}\text { Sand Layer } \\
\text { Present }\end{array}$} & \multicolumn{2}{|c|}{ Annual Drainage $(\mathrm{cm})$} \\
\hline & $\begin{array}{c}\text { Dry Year } \\
(16.0 \mathrm{~cm} / \mathrm{yr})\end{array}$ & $\begin{array}{c}\text { Wet Year } \\
(30.1 \mathrm{~cm} / \mathrm{yr})\end{array}$ \\
\hline No & $1.7^{(\mathrm{a})}$ & $7.8^{(a)}$ \\
\hline Yes & 1.8 & 7.8 \\
\hline
\end{tabular}

(a) Indicates results from 1985 study. 
this case with the new plant parameters resulted in a drainage rate of 0.4 $\mathrm{cm} / \mathrm{yr}$. This finding indicates that the mere presence of plants does not guarantee barrier performance. Some minimum plant presence (a combination of species, density, rooting depth, and phenology) is required to allow the plant community to withdraw sufficient quantities of water such that drainage through the barrier is reduced to $\langle 0.1 \mathrm{~cm} / \mathrm{yr}$.

\subsection{REVISED SOIL HYORAULIC PROPERTIES}

As stated elsewhere (e.g., U.S. Department of Energy 1986; Lu, Phillips, and Adams 1982; Fayer et al. 1985), soil hydraulic properties play a major role in barrier performance. Table 3.3 contains the results for the 1985 RN2 soil and the 1986 RN2 soil with revised soil hydraulic properties (both soils without grave1). Note that drainage approaches zero in both the dry and wet years when the revised soil hydraulic properties are used. Once again, this illustrates the importance of the fine soil layer's hydraulic properties to barrier performance. The implication for future modeling work is that considerable effort must be expended, both in the laboratory and field, to obtain quality data that fully characterize the hydraulic properties of all relevant barrier soll materials.

\subsection{HISTORICAL WEATHER RECORO}

In the 1985 study and the one-dimensional simulations reported above, an "average" rain year (i.e., an average annual precipitation distribution) was

TABLE 3.3. Simulated Annual Drainage Using the Revised Soll Hydraulic Properties for the RN2 Soll (no surface gravel)

\begin{tabular}{lcc} 
So11 Type & \multicolumn{2}{c}{ Annual Drainage (cm) } \\
\cline { 2 - 3 } \multicolumn{1}{c}{ RN2 } & $\frac{\begin{array}{c}\text { Dry Year } \\
(16.0 \mathrm{~cm} / \mathrm{yr})\end{array}}{0.4^{(\mathrm{a})}}$ & $\frac{(30.1 \mathrm{~cm} / \mathrm{yr})}{3.7^{(\mathrm{a})}}$ \\
$\begin{array}{l}\text { RN2 with } \\
\text { revised } \\
\text { properties }\end{array}$ & & \\
& $(<0.1)$ & $(<0.1)$
\end{tabular}

(a) Indicates results from the 1985 study. 
used in which annual precipitation was 16.0 and $30.1 \mathrm{~cm}$ for the dry and wet years, respectively. For the simulations reported in Table 3.4, however, the actual precipitation and meteorological data for the 25 years from 1961 to 1985 were used (mean precipitation $=16.2 \mathrm{~cm} / \mathrm{yr}$ ). For the enhanced precipitation simulations, the actual precipitation for each year was increased by a factor of 1.86 , such that the enhanced mean precipitation was identical to that used in the 1985 study $(30.1 \mathrm{~cm} / \mathrm{yr})$. In both cases modeled here, however, each yearly precipitation distribution is unique and representative of what actually occurred at Hanford. The barrier configuration for all years was the 1.5-m depth of RN2 soil with gravel mixed into the surface layer, no plants, and no intermediate sand layer.

The results of Table 3.4 indicate that, for the particular barrier design modeled, drainage varied quite dramatically from year to year, ranging from 0.9 to $7.5 \mathrm{~cm} / \mathrm{yr}$. The mean, $3.0 \mathrm{~cm} / \mathrm{yr}$, is nearly double the $1.7 \mathrm{~cm} / \mathrm{yr}$ reported for the "average" rain year. This finding points out that the assumption that an "average" rain year (i.e., distribution) can be used to model barrier performance would be wrong in an absolute sense and may also be questionable in a relative sense (e.g., in comparison studies).

The results under the enhanced precipitation regime (Table 3.4) are similar. Drainage varied between 1.8 and $19.3 \mathrm{~cm} / \mathrm{yr}$, with a mean of $10.2 \mathrm{~cm} / \mathrm{yr}$ that is about $30 \%$ greater than that reported in the 1985 study for the enhanced "average" rain year.

This particular study indicates the importance of yearly precipitation distribution, and its variation from year to year, on barrier performance. The implication for testing of long-term barrier performance is that barrier drainage rates measured in the field over a 3- to 5-year period will not reflect the long-term barrier performance to be expected under the myriad precipitation distributions that are possible over thousands of years. Therefore, to assess long-term barrier performance, the current unsaturated zone model should be used to demonstrate that drainage through the barrier is limited to a specified rate $(\mathrm{e} . \mathrm{g} ., 0.05 \mathrm{~cm} / \mathrm{yr})$ under a variety of precipitation distributions that might be expected at the Hanford Site. 
TABLE 3.4. Simulated Annual Drainage for 25 Years of Hanford Weather with Actual and Enhanced Precipitation (RN2 soil with gravelled surface and no plants)

\begin{tabular}{|c|c|c|c|c|}
\hline Year & $\begin{array}{l}\text { Actual } \\
\text { Precip. } \\
\text { (cm/yr) }\end{array}$ & $\begin{array}{r}\text { Simulated } \\
\text { Drainage } \\
\text { (cm/yr) }\end{array}$ & $\begin{array}{c}\text { Enhanced } \\
\text { Precip. } \\
\text { (cm/yr) }\end{array}$ & $\begin{array}{r}\text { Simulated } \\
\text { Drainage } \\
\quad(\mathrm{cm} / \mathrm{yr}) \\
\end{array}$ \\
\hline 1961 & 17.4 & 3.2 & 32.2 & 10.7 \\
\hline 1962 & 15.4 & 1.6 & 28.6 & 5.4 \\
\hline 1963 & 16.0 & 2.7 & 29.7 & 10.7 \\
\hline 1964 & 13.7 & 1.8 & 25.4 & 5.0 \\
\hline 1965 & 9.3 & 3.7 & 17.2 & 12.7 \\
\hline 1966 & 15.0 & 1.3 & 27.9 & 4.1 \\
\hline 1967 & 8.3 & 2.5 & 15.4 & 10.6 \\
\hline 1968 & 15.1 & 1.1 & 28.0 & 2.8 \\
\hline 1969 & 16.1 & 2.2 & 30.0 & 12.2 \\
\hline 1970 & 16.1 & 5.1 & 29.8 & 15.6 \\
\hline 1971 & 16.0 & 1.5 & 29.7 & 4.5 \\
\hline 1972 & 16.2 & 1.4 & 30.1 & 7.5 \\
\hline 1973 & 21.0 & 2.4 & 39.0 & 11.5 \\
\hline 1974 & 13.4 & 7.5 & 25.0 & 16.8 \\
\hline 1975 & 18.9 & 2.4 & 35.2 & 9.1 \\
\hline 1976 & 7.6 & 1.7 & 14.1 & 5.4 \\
\hline 1977 & 16.2 & 0.9 & 30.2 & 1.8 \\
\hline 1978 & 16.6 & 3.9 & 31.3 & 15.3 \\
\hline 1979 & 14.0 & 2.1 & 26.0 & 6.4 \\
\hline 1980 & 24.6 & 5.2 & 45.6 & 19.3 \\
\hline 1981 & 17.9 & 3.9 & 33.2 & 11.6 \\
\hline 1982 & 20.3 & 3.0 & 37.6 & 10.3 \\
\hline 1983 & 28.1 & 5.5 & 52.2 & 19.3 \\
\hline 1984 & 18.4 & 5.4 & 34.2 & 17.1 \\
\hline 1985 & 12.9 & 2.8 & 24.0 & 9.8 \\
\hline Mean & 16.2 & 3.0 & 30.1 & 10.2 \\
\hline
\end{tabular}




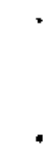




\subsection{DESCRIPTION OF TWO-DIMENSIONAL SIMULATIONS}

The following work is a continuation of the two-dimensional modeling effort begun in 1985 (Fayer et al. 1985). The goal is to understand how different features of the barrier design limit the flow of water through the waste zone. For this part of the study, we focused on a particular waste storage form, the subsurface tanks. The issues to be examined here are the effect (on flow past the waste) of soll type, recharge rate, distance from the tank to the barrier edge, and soil layering. The computer code used in this analysis is UNSAT2 (Davis and Neuman 1983).

The RN2 soil was used in the 1985 study. This material was subsequently determined to be nonrepresentative of fill material surrounding some of the waste tanks. Reports by Last and Marratt (1978a, 1978b) indicate that the fill material around the tanks in the 241-AN and 241-AW tank farms is very coarse, consisting of "pebbles and very coarse to coarse sand." For this reason, materials more representative of the fill material were chosen for simulation. They include the material in the 200-Area lysimeter (Finlayson, Nelson, and Baca 1978), which hereafter will be called soil A200; and material known as soil sample 241-AP-1 (hereafter AP1) from the 241-AP Tank Farm (U.S. Department of Energy 1986). The AP1 soll is classified as a loamy sand and is slightiy coarser than the $A 200$ soil.

Two of the simulations were designed to indicate the effect of different recharge rates outside the edge of the barrier on water flow past the tank. The recharge rates were 5.0 and $0.5 \mathrm{~cm} / \mathrm{yr}$. The effects of the distance between the waste and the barrier edge were studied by conducting simulations with distances of 10 and $20 \mathrm{~m}$. These distances are identical to those studied in 1985, the difference being a change in soll material (i.e., the RN2 soil was replaced with the AP1 soil).

In the last simulation, a horizontal 2-m-thick layer of fine soil material was located at the same elevation as the base of the waste tank. The layer was truncated directly beneath the barrier edge, as it would be when a 
site is excavated before tank construction. The question is whether such a layering sequence outside of the barrier zone would significantly affect flow beneath the barrier and past the waste.

\subsection{BARRIER REPRESENTATION}

The barrier conceptualization is shown in Figure 4.1. It is nearly identical to that used in 19B5, except that the area representing the waste tank has been increased. The waste tank's height in the 1985 simulations was $8 \mathrm{~m}$, but waste tanks, such as single-shell tanks, have heights that vary from 8.2 to $14.3 \mathrm{~m}$ (from figures in Brown 1960). Therefore, in this report, the tank height is shown to be $12 \mathrm{~m}$.

The finite element grid used to represent the flow domain illustrated in Figure 4.1 is nearly identical to the 1985 grid except beneath the zone of 15 $\mathrm{cm} / \mathrm{yr}$ recharge. In that zone, the grid spacing was altered to ensure that the $15 \mathrm{~cm} / \mathrm{yr}$ recharge occurred over the prescribed 2-m width. The new grid is shown in Figure 4.2 .

Only the layered system simulation used a significantly different grid. That grid is shown in Figure 4.3. Note the finer grid mesh in the vicinity of the fine-textured soil layer.

\subsection{SOIL PROPERTIES}

The basic soil material used in these simulations was the AP1 soil. Hydraulic properties of the AP1 soil, as well as those for the RN2 and A200 soils, are shown in Figure 4.4. The fine-textured material was represented by sample AP-6 from the 241-AP tank farm (U.S. Department of Energy 1986). Hydraulic properties for the AP6 soil are also shown in Figure 4.4.

In all of the simulations, the assumption has been made that the soil material is homogeneous between the soil surface and the water table $76 \mathrm{~m}$ below. In fact, according to Brown (1960), there is a sequence of layers of different soils that is particular to each waste site; in this case, singleshell tank sites. When the modeling analysis reaches the point where flow from the waste tank to the water table is analyzed, the natural layering sequences will have to be taken into account. 


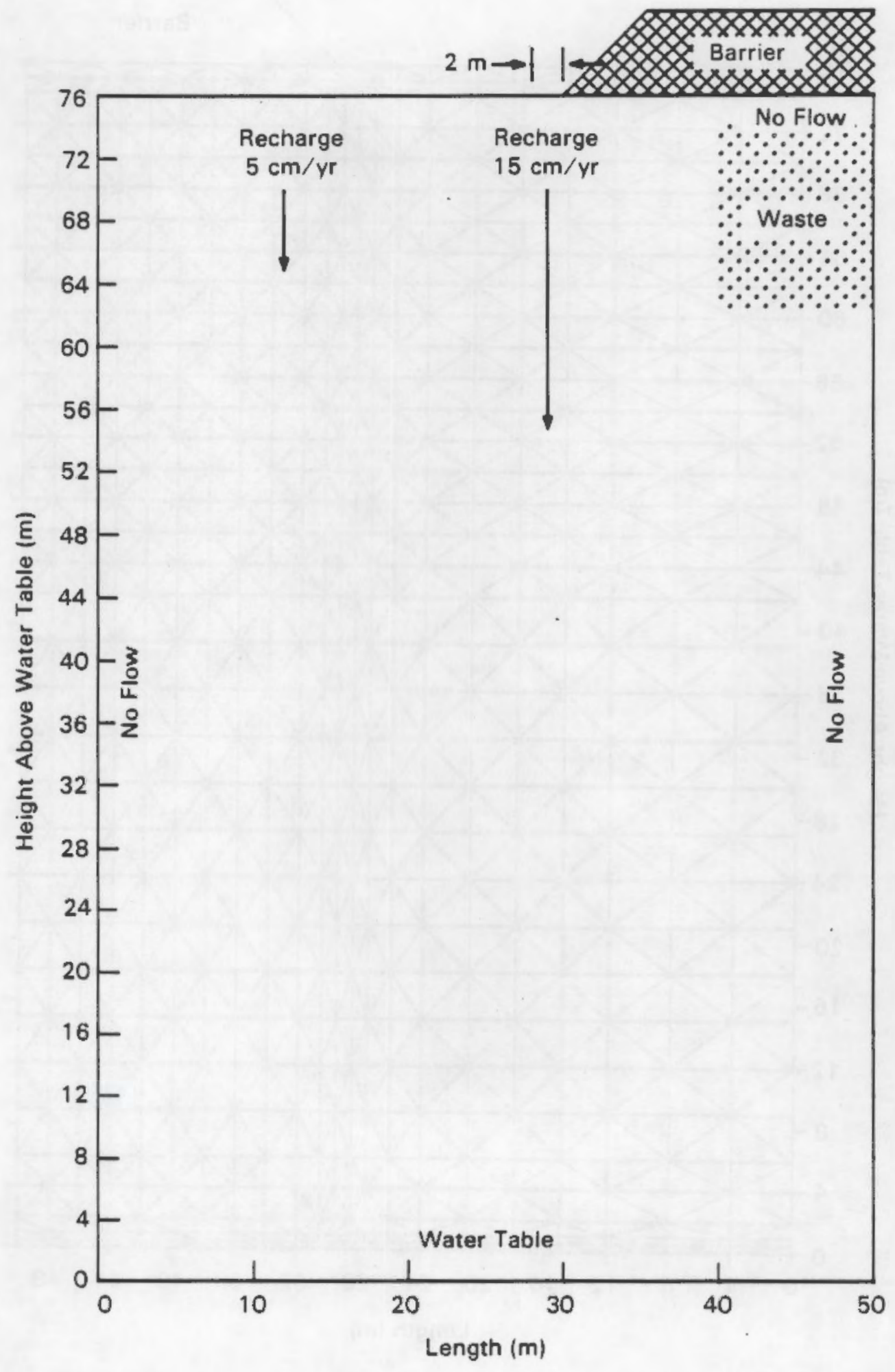

FIGURE 4.1. Barrier Conceptualization for Two-Dimensional Modeling 


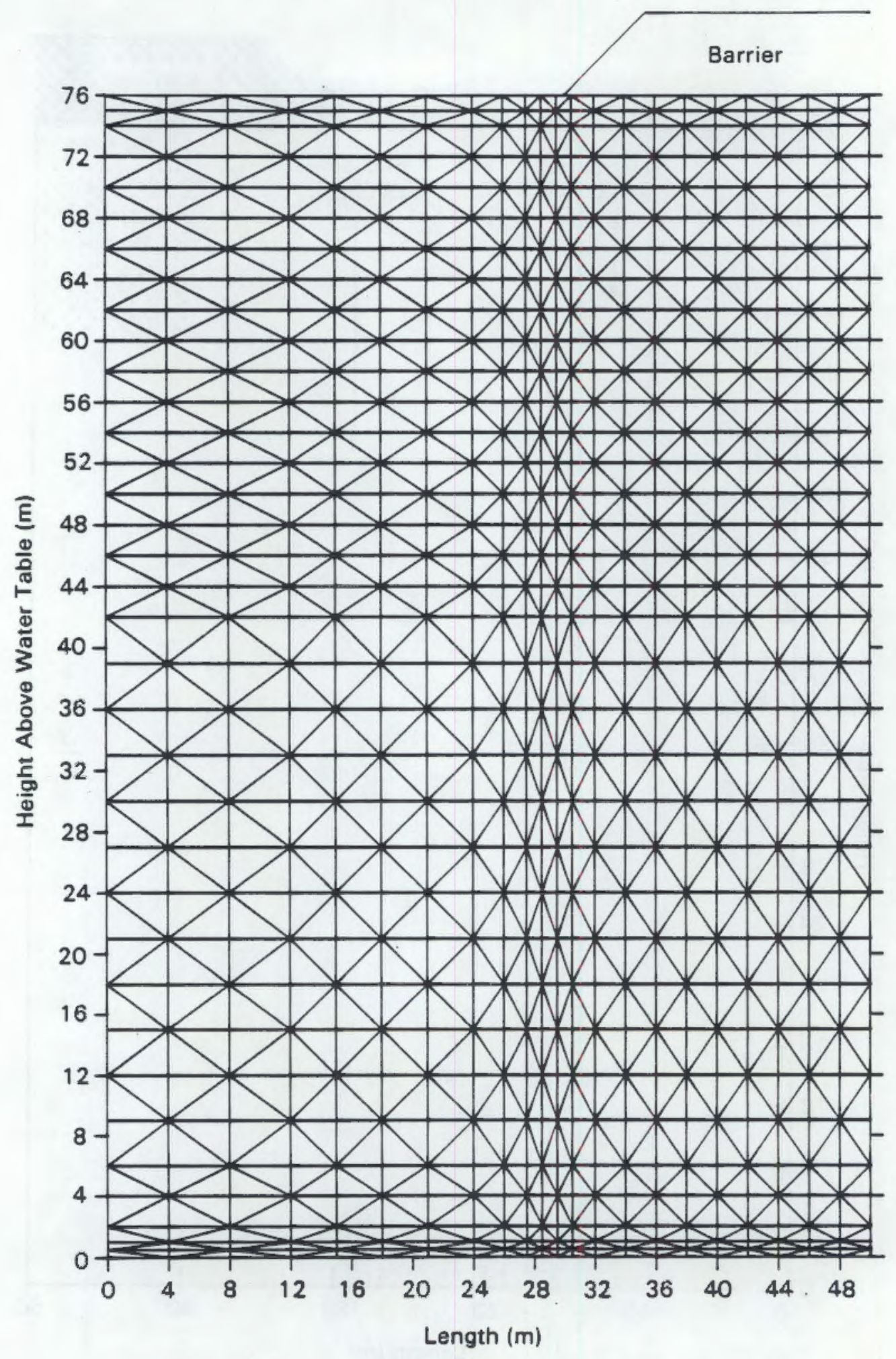

FIGURE 4.2. Finite Element Grid for the Majority of Two-Dimensional Simulations 


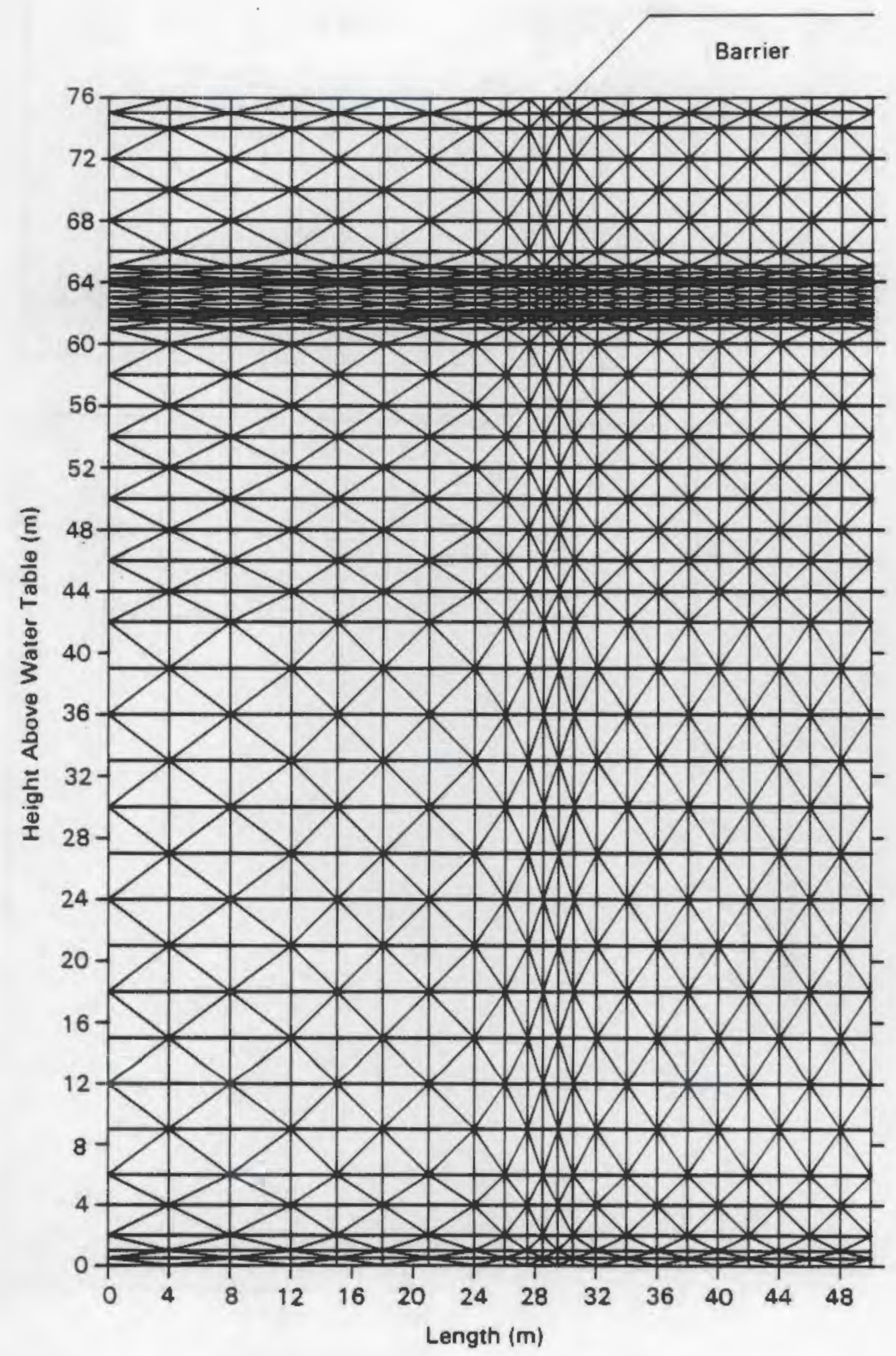

FIGURE 4.3. Finite Element Grid for Two-Dimensional Simulation of Barrier with Fine-Textured Soil Layer Between 62- and 64-m Elevations (1081 nodes, 2024 elements) 

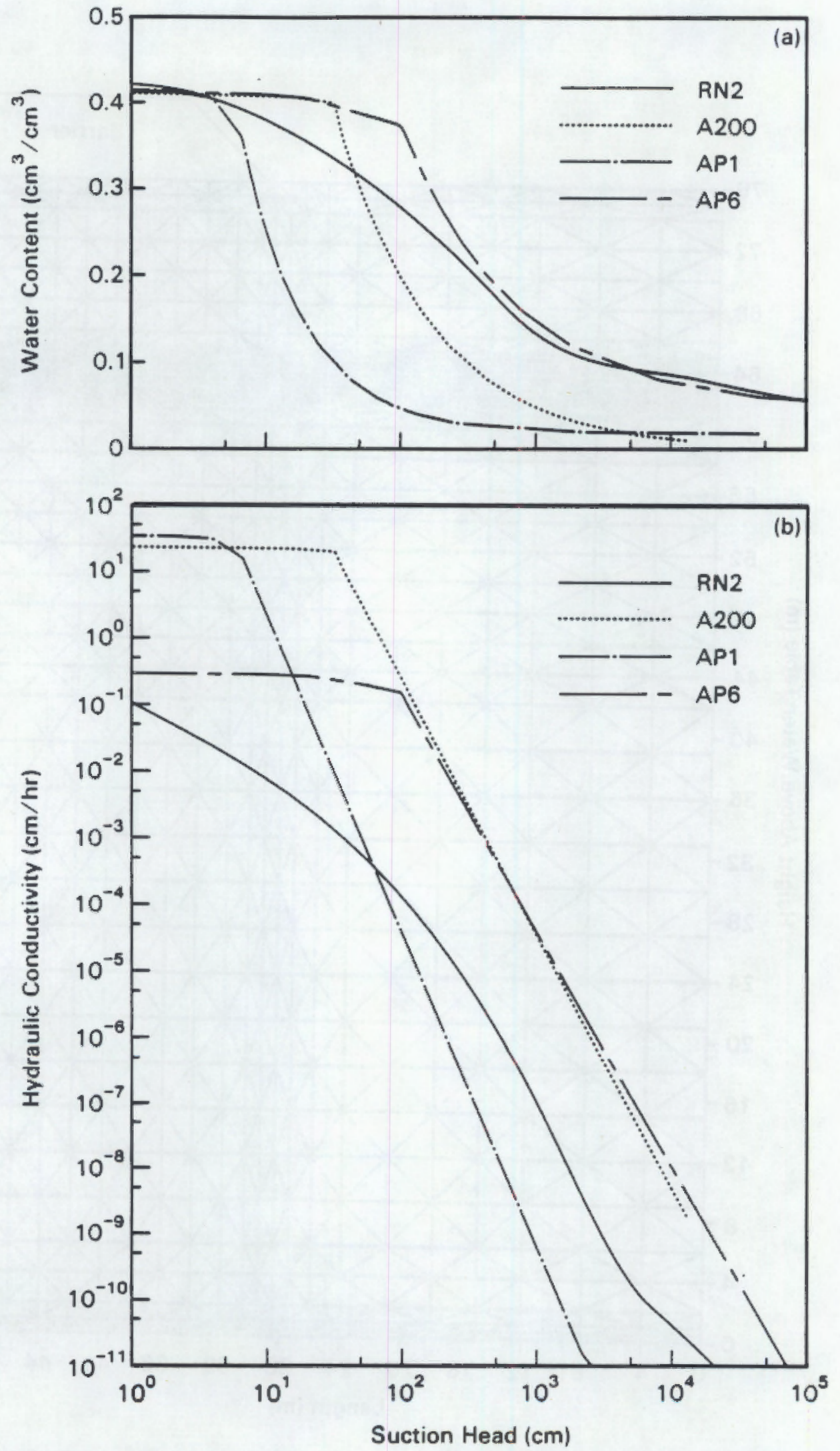

FIGURE 4.4. Moisture Characteristics (a) and Hydraulic Conductivity Functions (b) of Materials Used in Two-Dimensional Simulations 


\subsection{INITIAL CONDITIONS}

Just as in the 1985 study, initial conditions were determined for each simulation case by modeling a small vertical slice of the area represented in Figure 4.1. The recharge rate for each case was applied at the upper surface, and a constant pressure head of zero was maintained at the lower boundary. Lateral flow was zero. These small simulations were run until they reached a steady state in which the vertical pressure head distribution did not change measurably over time. When each full simulation case was started, the vertical distribution of pressure head just determined was applied to the entire area to be modeled. This technique of initializing the system also applied to the area in Figure 4.1 that would be occupled by the fill material surrounding the tank.

\subsection{BOUNDARY CONDITIONS}

As shown in Figure 4.1, the boundary conditions for the simulations are the same as in 1985 . The entire bottom boundary is a constant pressure head of zero as if it were a water table. The two side boundaries are considered "no-flow" boundaries, the left boundary because it is far enough from the barrier that flow is essentially vertical and the right boundary because it is a plane of symmetry. The upper boundary differs for each of the simulation cases. After time zero, the boundary located beneath the barrier is considered impermeable; i.e., a "no-flow" boundary. The upper boundary outside of the barrier receives the recharge rate specified for that particular scenario (either 5.0 or $0.5 \mathrm{~cm} / \mathrm{yr}$ ). In all cases, the 2-m width of upper boundary just outside the barrier edge receives $15 \mathrm{~cm} / \mathrm{yr}$ of recharge, thus mimicking an undesirable increase in recharge caused by runoff from the barrier. The choice of $15 \mathrm{~cm} / \mathrm{yr}$ recharge at the edge of the barrier is arbitrary and is meant only to provide a stress on the system to observe the system's response. As Lu, Phillips, and Adams (1982) point out, the most desirable barrier design would be a barrier with no off-flow (i.e., no runoff). 


\subsection{RESULTS OF TWO-DIMENSIONAL SIMULATIONS}

In 1985, the results of the two-dimensional simulations were displayed as contour plots of total head and water content. Comparisons between barrier designs were made according to whether the total head profiles were horizontal around the waste tank. Horizontal total head contours indicated strictly vertical flow, which meant that water flow toward the waste from outside of the barrier was unlikely. This type of analysis is only qualitative and does not provide a quantitative estimate of the effect of barrier design on flow past the waste. An alternative is to calculate actual fluxes.

Ideally, fluxes at any point could be calculated as the product of hydraulic conductivity and the total head gradient along the flow path. Because the UNSAT2 code does not explicitly output fluxes or head gradients, an approximation was made. In this case, the total head gradient was approximated at unity. At time zero, a unit gradient existed because of the steady-state recharge initialization procedure. As each simulation progressed, the vertical gradient remained near unity beyond the barrier edge, but decreased to less than unity beneath the barrier. Assuming unit gradient conditions along all flow paths, at all times, and at points in the profile below or to the left of the waste tank, resulted in only slight overestimates $(<10 \%)$ of the flux at later times in the simulation. For comparison purposes, the flux at the bottom-left corner of the waste tank was calculated at selected times for each simulation case. These fluxes were then plotted as a function of time, and inferences regarding barrier performance were drawn from the plotted fluxtime relationships.

Table 5.1 contains a summary of the simulation variables. Each simulation required a minimum of 24 to 48 hours of computer time (CPU time on a VAX $11 / 780$ ) to simulate 500 years (if everything was working perfectly). Additional computer time was required for the cases with more nodes than usual.

\subsection{SOIL TYPE}

Three simulations can be directly compared to contrast the effect of soil type. They are Case A (RN2 soil), which was simulated in 1985, Case 1 
TABLE 5.1. Summary of Two-Dimensional Simulation Variables

\begin{tabular}{|c|c|c|c|c|c|}
\hline Case & $\begin{array}{l}\text { No. of } \\
\text { Nodes }\end{array}$ & $\begin{array}{c}\text { No. of } \\
\text { Elements }\end{array}$ & Soil & $\begin{array}{l}\text { Recharge Rate } \\
\text { Beyond Barrier } \\
(\mathrm{cm} / \mathrm{yr}) \\
\end{array}$ & $\begin{array}{c}\text { Distance Between Waste } \\
\text { and Barrier Edge } \\
(\mathrm{m})\end{array}$ \\
\hline$A^{(a)}$ & 756 & 1400 & RN2 & 5.0 & 10 \\
\hline 1 & 828 & 1540 & $\mathrm{~A} 200$ & 5.0 & 10 \\
\hline 2 & 828 & 1540 & AP1 & 5.0 & 10 \\
\hline 3 & 828 & 1540 & AP1 & 0.5 & 10 \\
\hline 4 & 1008 & 1890 & AP1 & 5.0 & 20 \\
\hline $5^{(b)}$ & 1081 & 2024 & AP1 & 5.0 & 10 \\
\hline
\end{tabular}

(a) Case A was simulated in the 1985 study.

(b) Fine-textured soil layer between 62- and 64-m elevation.

(A200 soil), and Case 2 (AP1 soil). In all three cases, the barrier edge was $10 \mathrm{~m}$ from the waste tank, and the recharge rate outside the barrier was 5.0 $\mathrm{cm} / \mathrm{yr}$. The simulation results for each soil at 500 years are plotted in Figures 5.1 through 5.3 . The first observation to be made is the nearly horizontal total head contours in the vicinity of the waste tank in the AP1 soil (Case 2). The horizontal contours indicate that flow is nearly vertical, and thus little of the water infiltrating outside the barrier flows under the barrier to the waste form. In this case, the water flowing past the waste is mostly the water initially present in the fill material above and around the waste. This finding would suggest that, for new sites, efforts be made to pack around the waste tank with dry material.

The second observation from Figures 5.1 through 5.3 are the differences in moisture content profiles. Because each case represents a different soil type, actual values of moisture content cannot be compared. What does stand out, however, is the wide spatial distribution of moisture content contours in Case $A$ and Case 1 and the tight distribution in Case 2. This result suggests that the $15 \mathrm{~cm} / \mathrm{yr}$ recharge input is dissipated over a larger area for soils RN2 and A200 than for soil AP1. In fact, the water in Case 2 appears to move in a fairly narrow "chimney" with relatively little lateral migration. Such a finding indicates that coarse-textured fill materials are desirable, because recharge flow is quickly routed downward before there is a chance for 


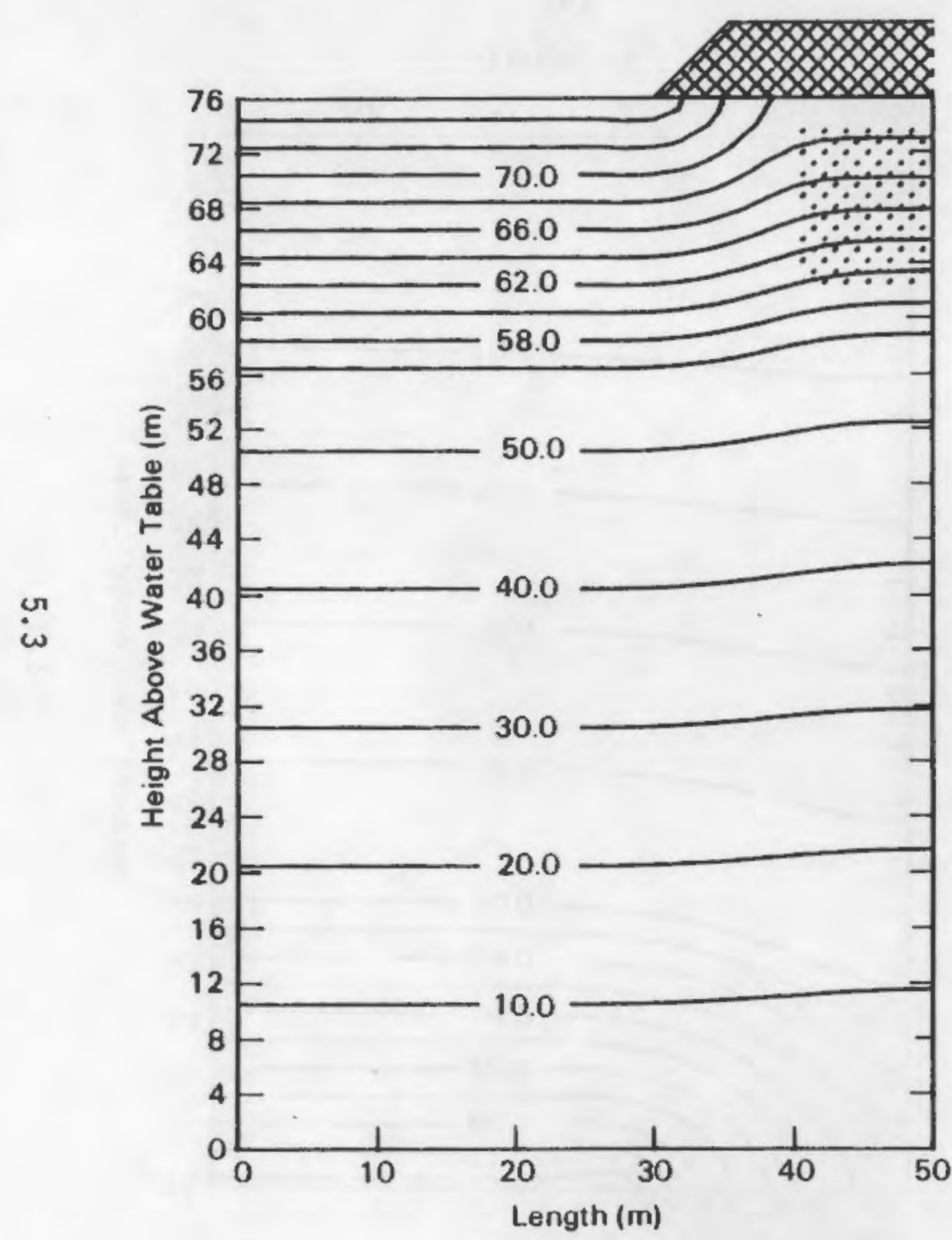

(a)

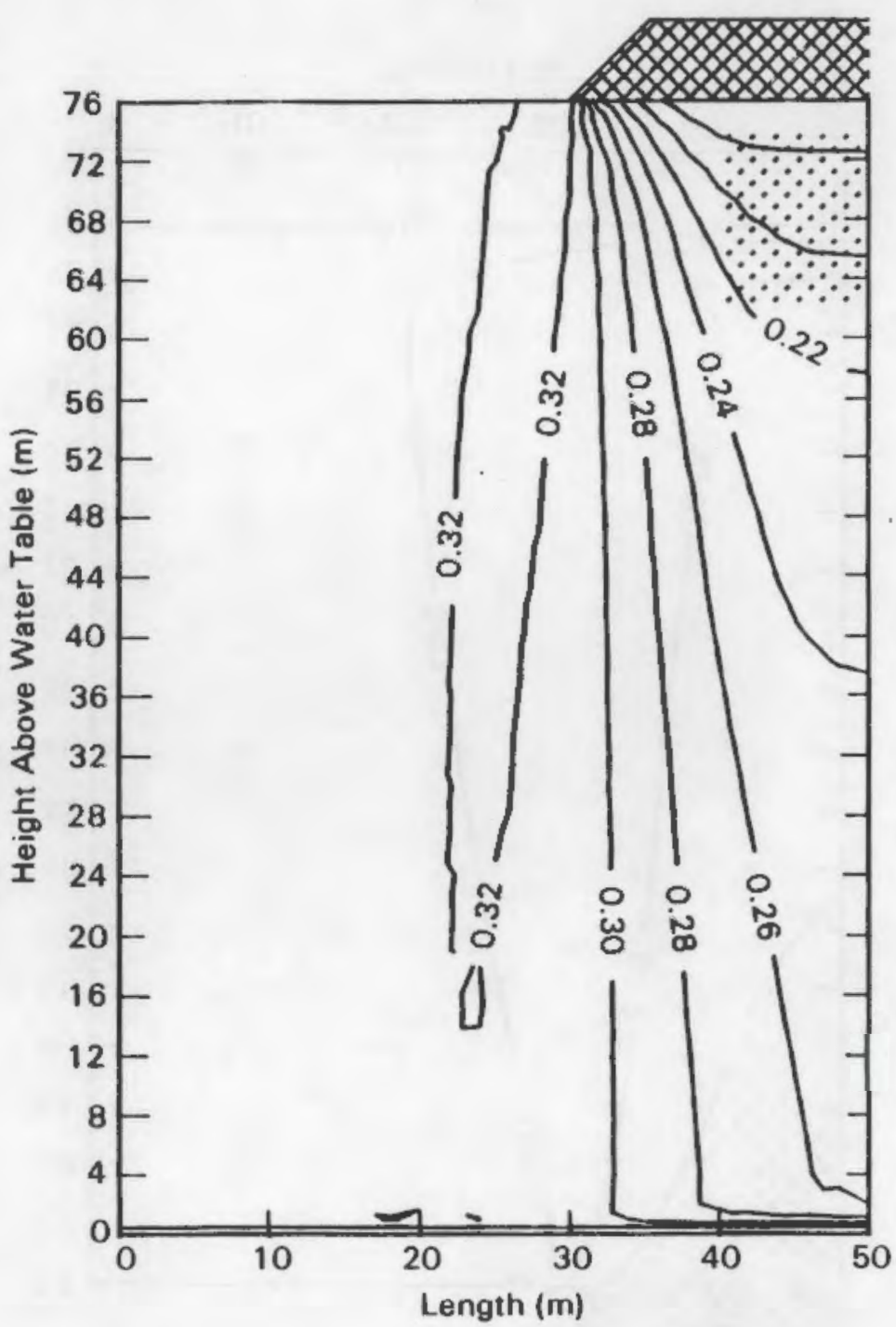

(b)

FIGURE 5.1. Simulated Total Head (a) and Water Content (b) Contours for Case A, $500 \mathrm{yr}$ 


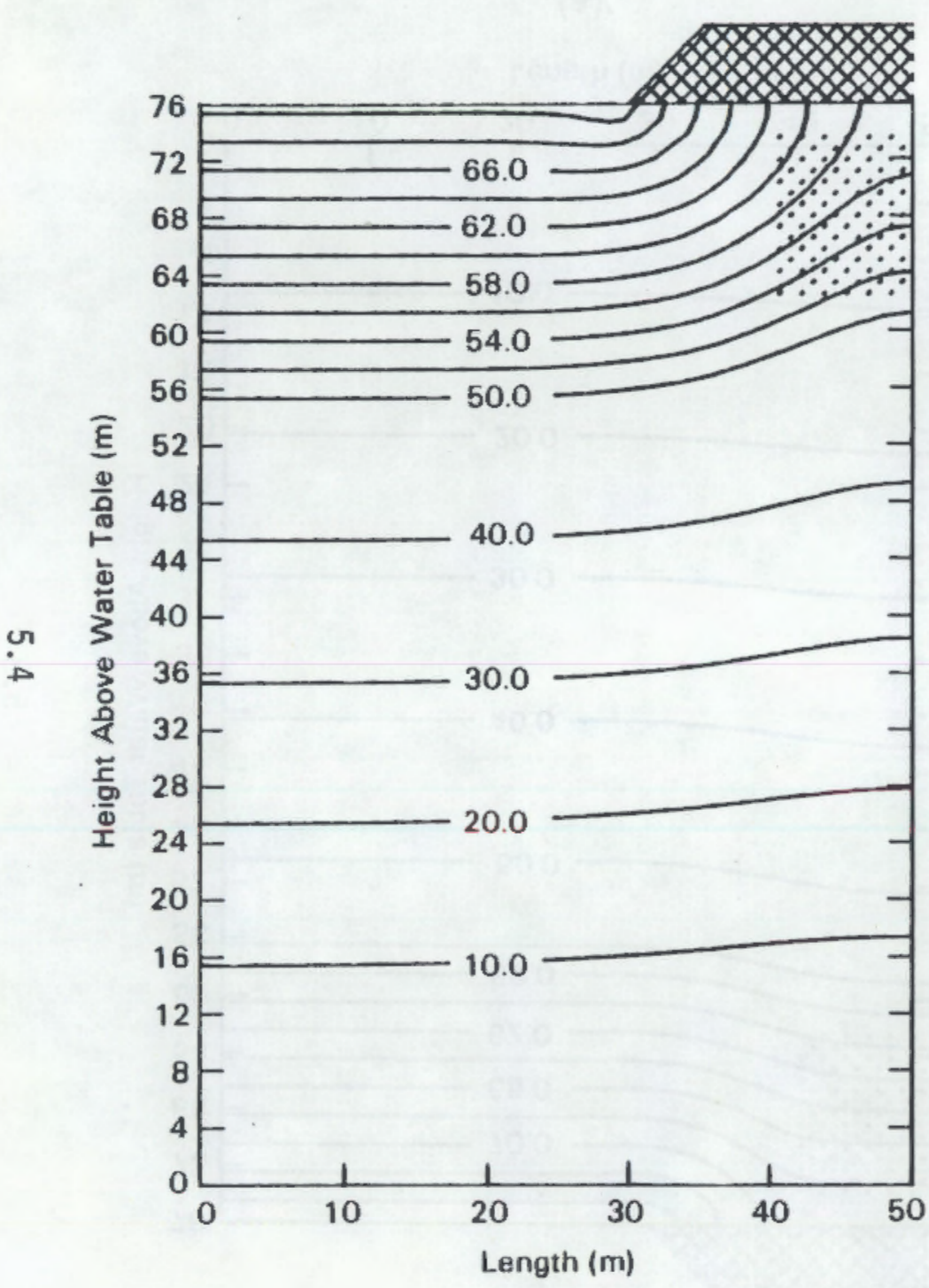

(a)

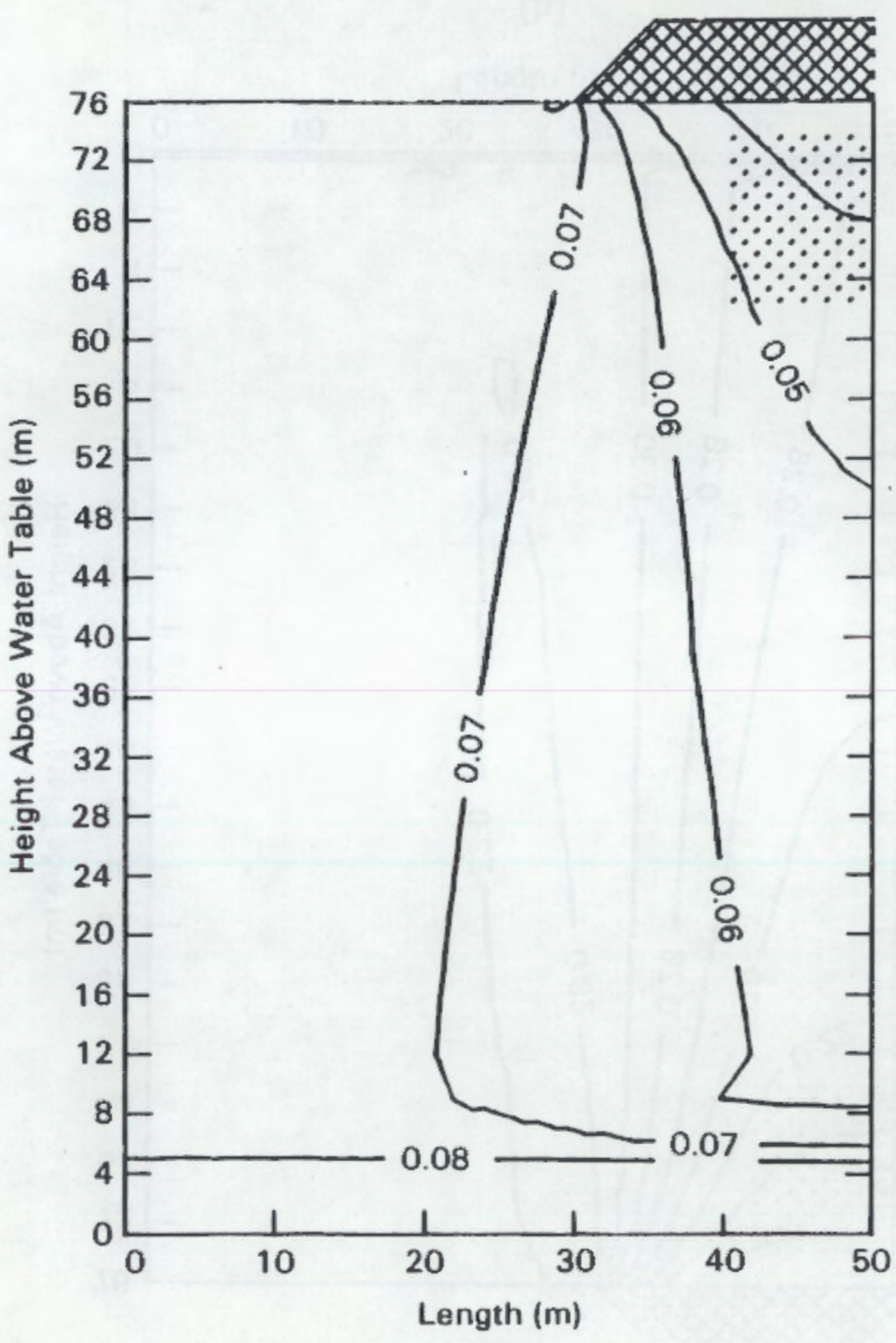

(b)

FIGURE 5.2. Simulated Total Head (a) and Water Content (b) Contours for Case 1, $500 \mathrm{yr}$ 


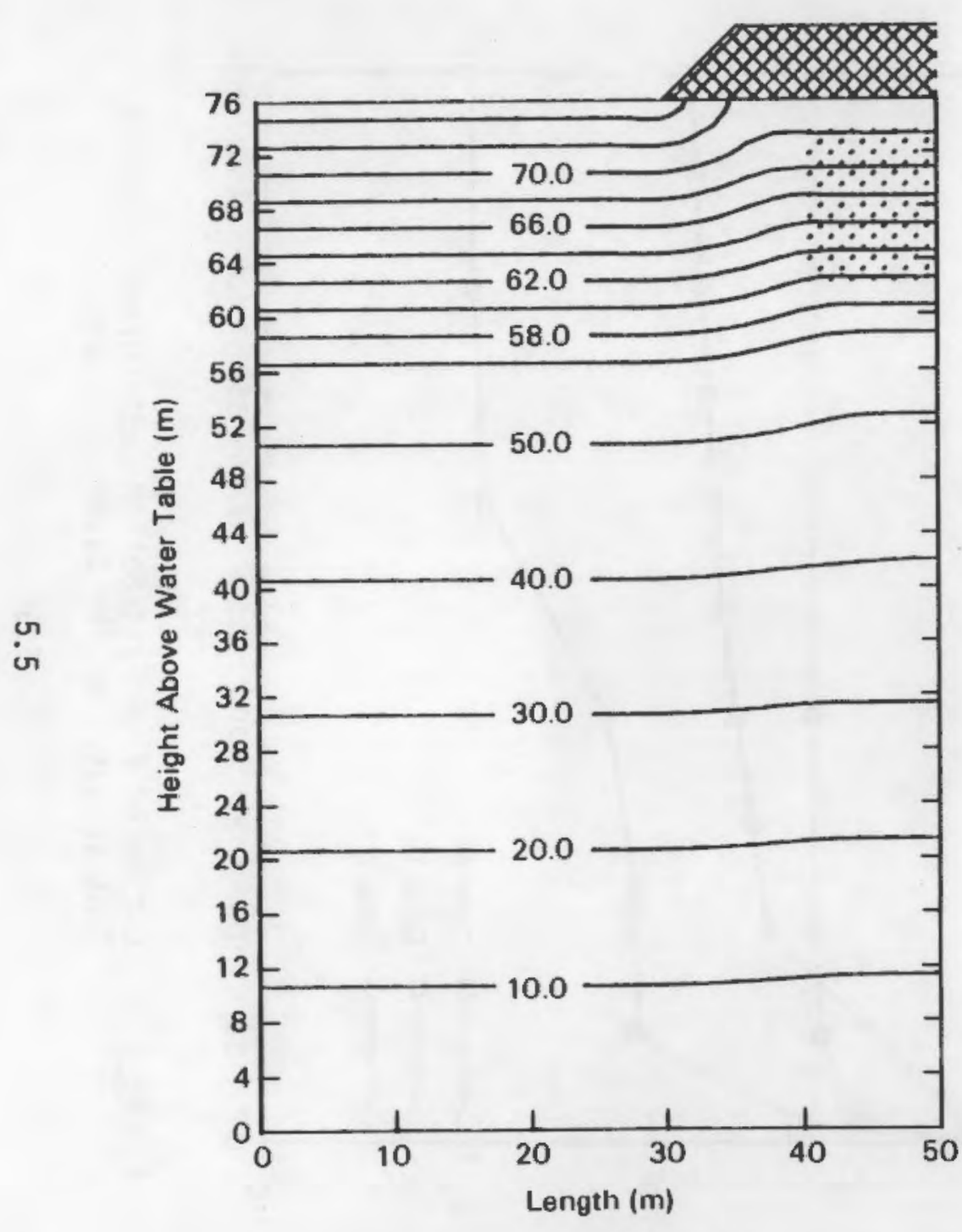

(a)

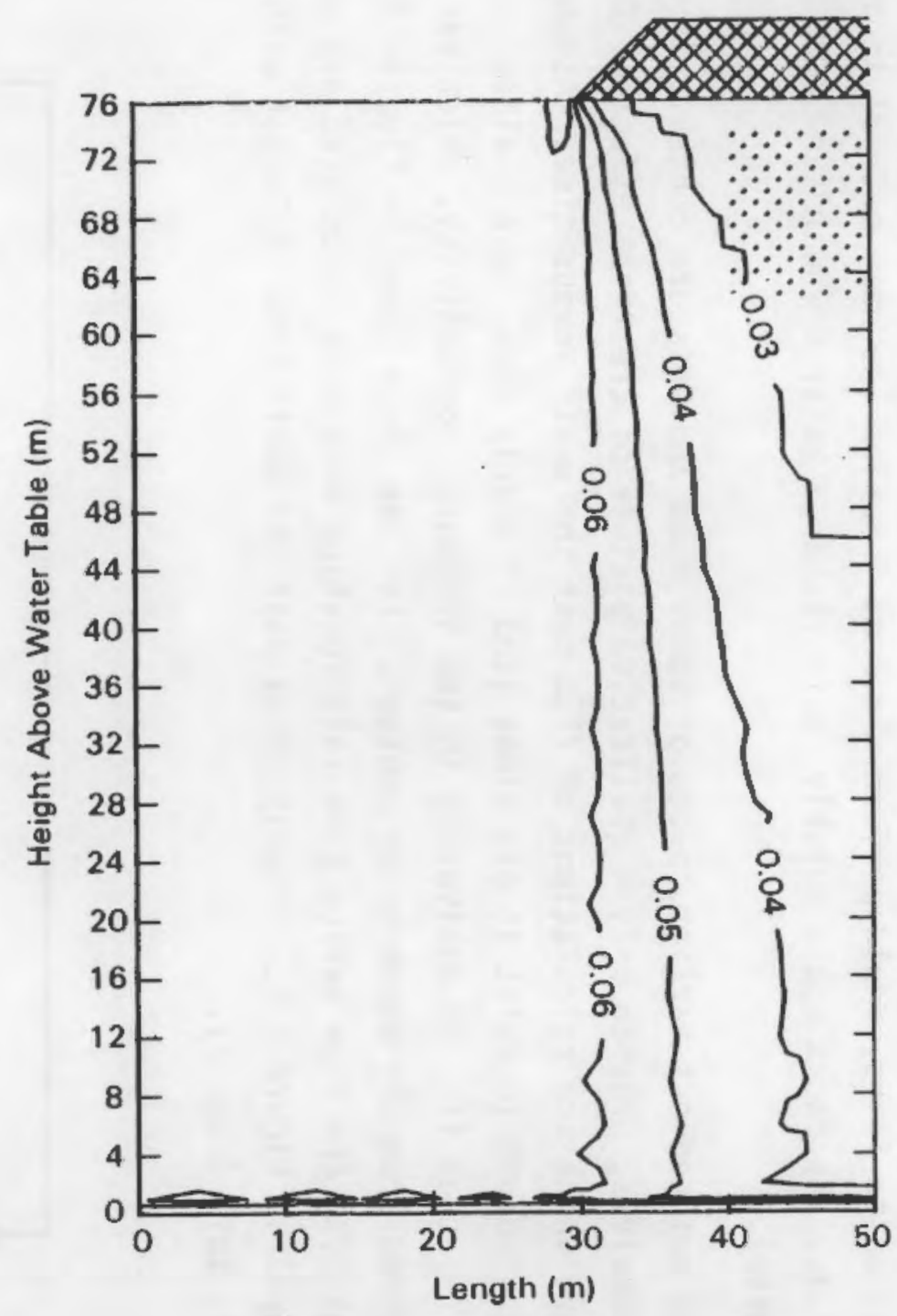

(b)

FIGURE 5.3. Simulated Total Head (a) and Water Content (b) Contours for Case 2, $500 \mathrm{yr}$ 
significant amounts of water to migrate under the barrier and contact the waste. Gravel packs, which are being considered for diffusion barriers encasing new waste forms, would perform the same function (perhaps better) as soil AP1 (i.e., the packs would quickly route recharge water downward and away from. the waste).

As pointed out earlier, plots of total head and moisture content, in and of themselves, provide only a qualitative picture of treatment effects. Of far more value are calculations of flux past the waste versus time. Assuming a unit gradient to exist at all times (and it nearly does, as explained earlier), then flux is equivalent to the hydraulic conductivity, which can be determined from the known water content. For the three cases in Figures 5.1 through 5.3, the flux versus time relationships have been calculated and are displayed in Figure 5.4. Clearly, flux past the waste tank is lowest within the AP1 soil (Case 2).

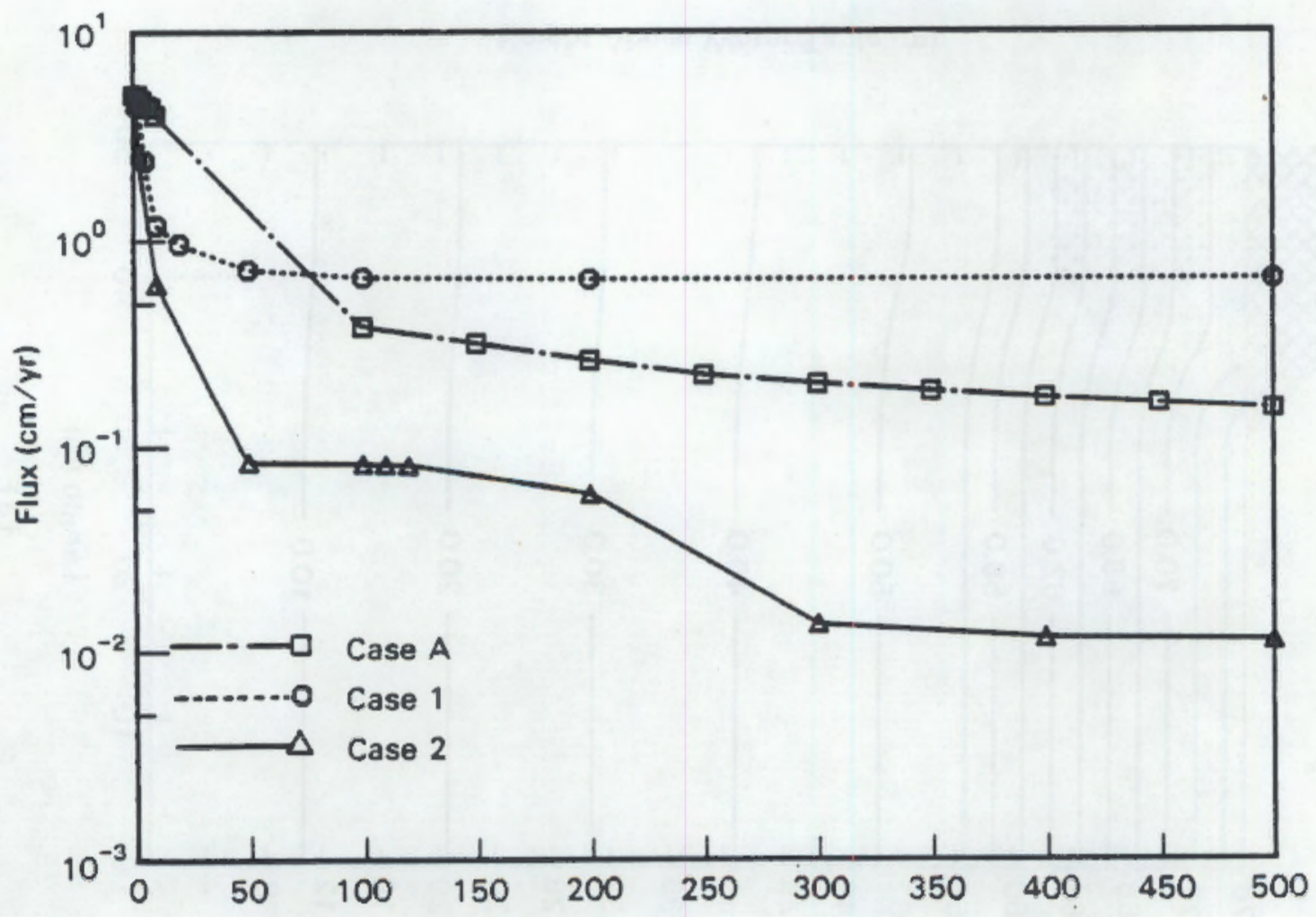

FIGURE 5.4. Estimated Flux Past Bottom-Left Corner of Waste Tank Versus Time for Cases $A, 1$, and 2 


\subsection{RECHARGE RATE}

Case 3 is identical to Case 2, except that the recharge rate outside the barrier is 0.5 instead of $5.0 \mathrm{~cm} / \mathrm{yr}$. The total head and moisture content profiles at 500 years are displayed in Figure 5.5. There is very little difference between the total head profiles of Cases 2 and 3 . The moisture content profiles are only slightly different. Outside the barrier, moisture contents are lower under $0.5 \mathrm{~cm} / \mathrm{yr}$ recharge. Beneath the barrier, however, there appears to be no discernable difference in moisture content. Beneath the $15 \mathrm{~cm} / \mathrm{yr}$ recharge point, the "chimney" of moisture remained intact. The high recharge rate dominates the flow regime and masks any effect beneath the barrier from decreasing recharge rates outside the barrier.

\subsection{DISTANCE BETWEEN WASTE AND BARRIER EDGE}

Case 4 is identical to Case 2, except that $10 \mathrm{~m}$ have been added to the right side of the modeled area in Figure 4.1, so that the waste tank is located $20 \mathrm{~m}$ from the barrier edge instead of $10 \mathrm{~m}$. The total head and moisture content simulation results are displayed in Figure 5.6. In comparable areas relative to the barrier edge, the results are identical to those of Case 2 (Figure 5.3). Because the waste form is $20 \mathrm{~m}$ distant, however, moisture contents around the waste tank have dropped to lower values than in Case 2. The effect of this result shows up in the calculation of fluxes. In Figure 5.7, the flux past the waste located $20 \mathrm{~m}$ from the barrier edge is lower than that for waste located only $10 \mathrm{~m}$ away.

An important question is whether there is any real difference in flux rates. Both cases result in fluxes less than $0.1 \mathrm{~cm} / \mathrm{yr}$ after 50 years, and, in fact, produce similar fluxes for the first 200 years. After 200 years, flux in Case 4 drops below that for Case 2 until, after 500 years, the flux in Case 4 is about $0.004 \mathrm{~cm} / \mathrm{yr}$ versus $0.01 \mathrm{~cm} / \mathrm{yr}$ for Case 2 . If the barrier drains at a rate as little as $0.1 \mathrm{~cm} / \mathrm{yr}$ (compared to the zero drainage rate assumed in these simulations), then the flux differences between Cases 2 and 4 are inconsequential in comparison to the recharge rate through the barrier. In this case, there would appear to be no benefit to be gained by increasing the distance between the barrier edge and the waste tank. 


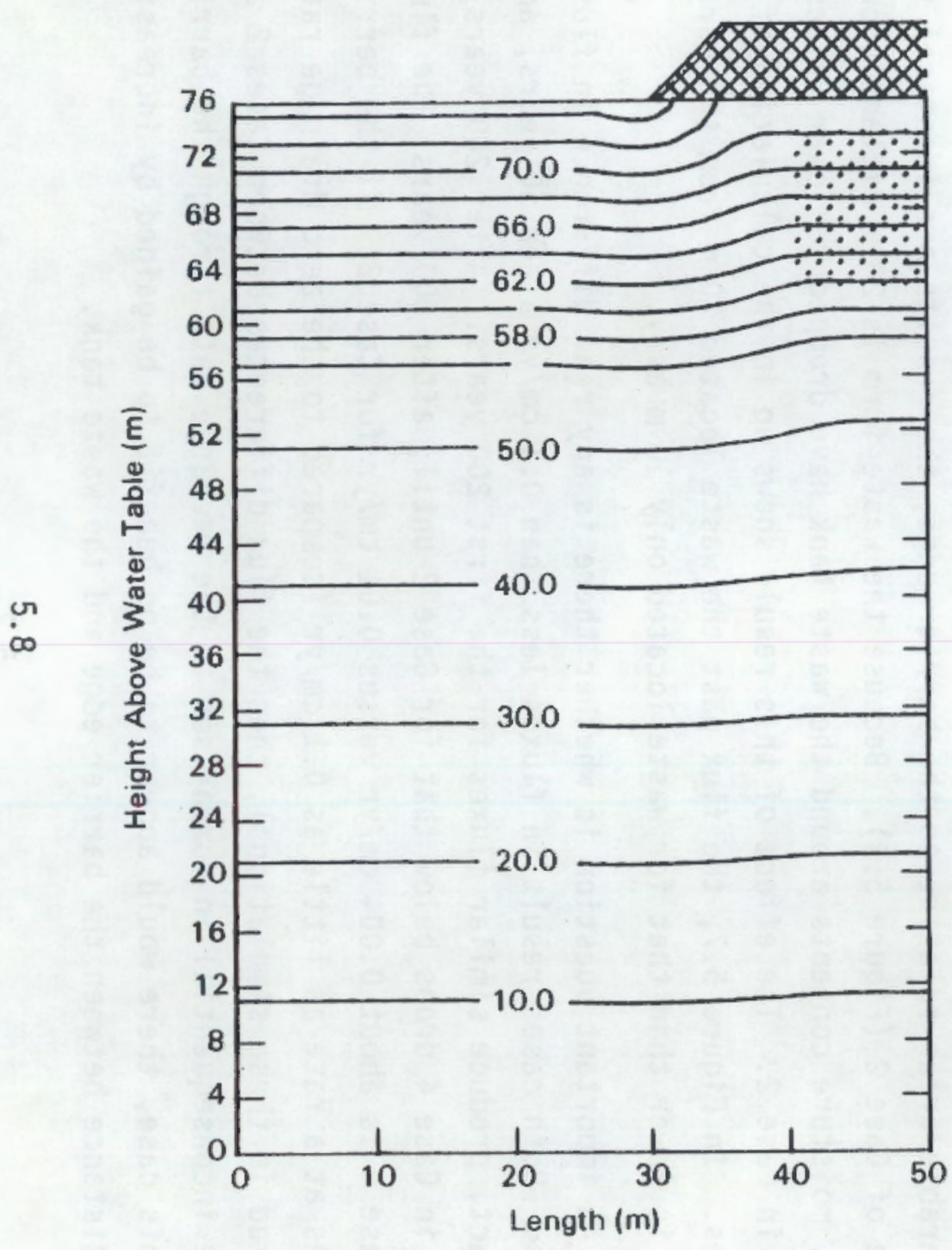

(a)

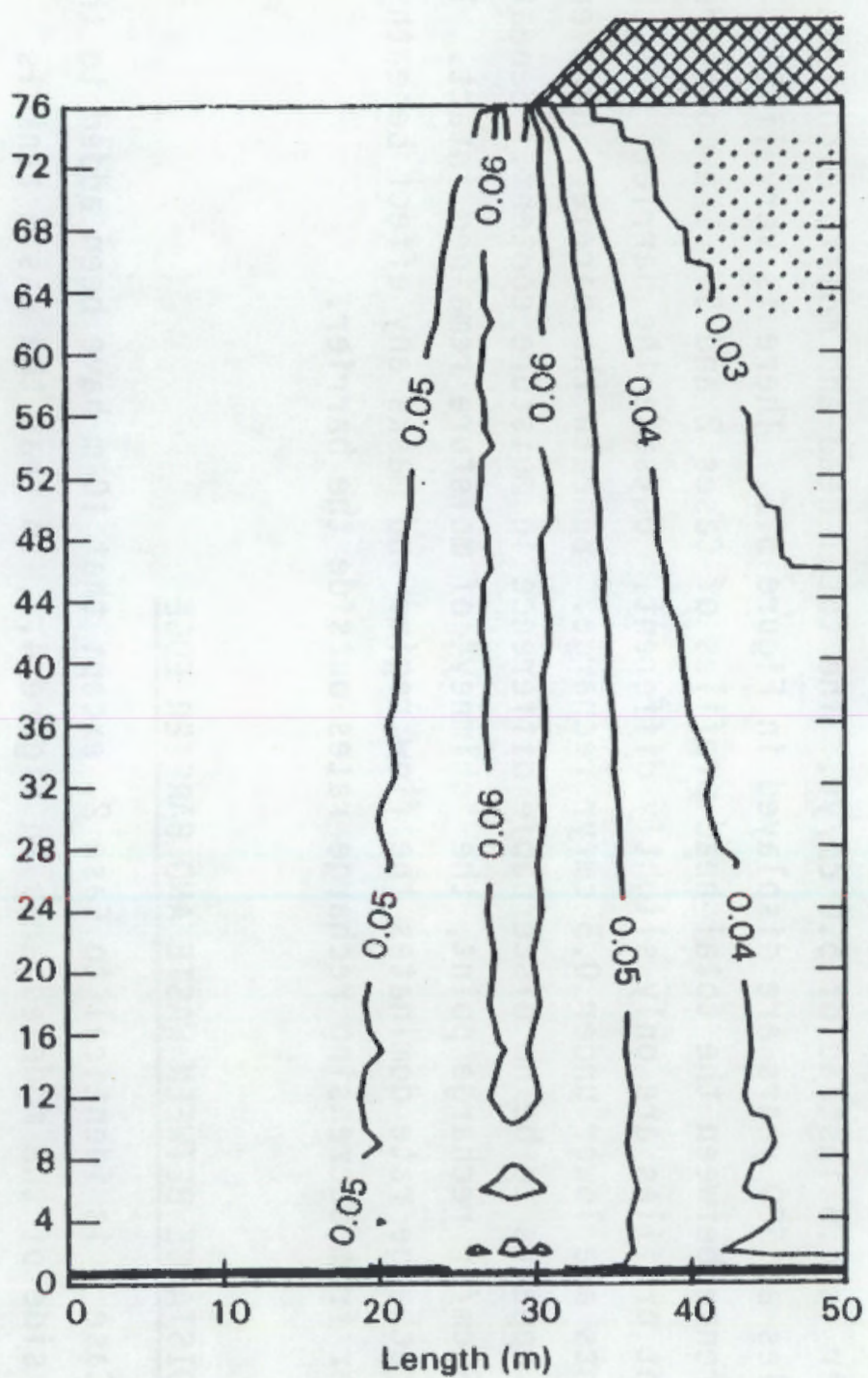

(b)

FIGURE 5.5. Simulated Total Head (a) and Water Content (b) Contours for Case 3,500 yr 


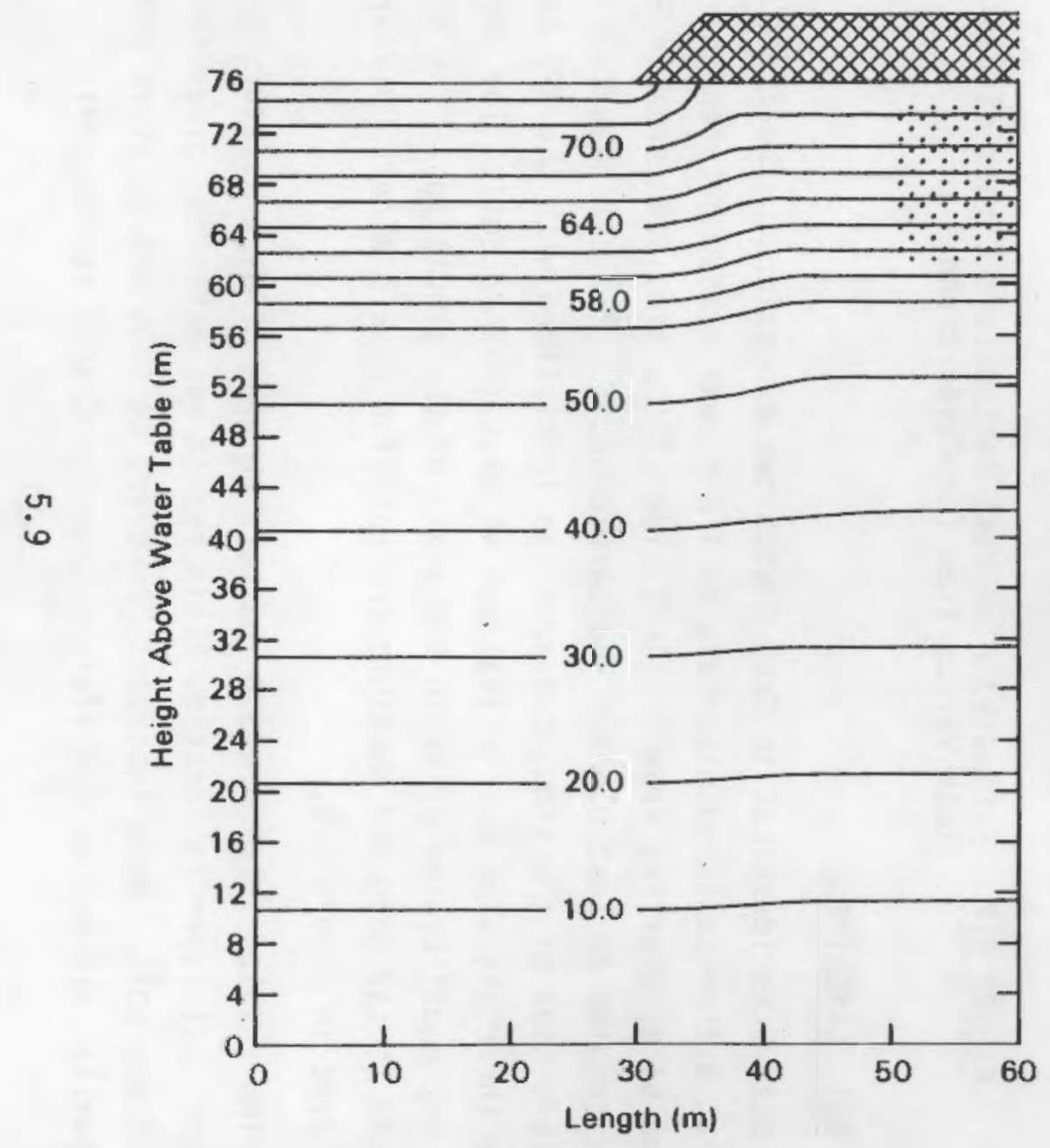

(a)

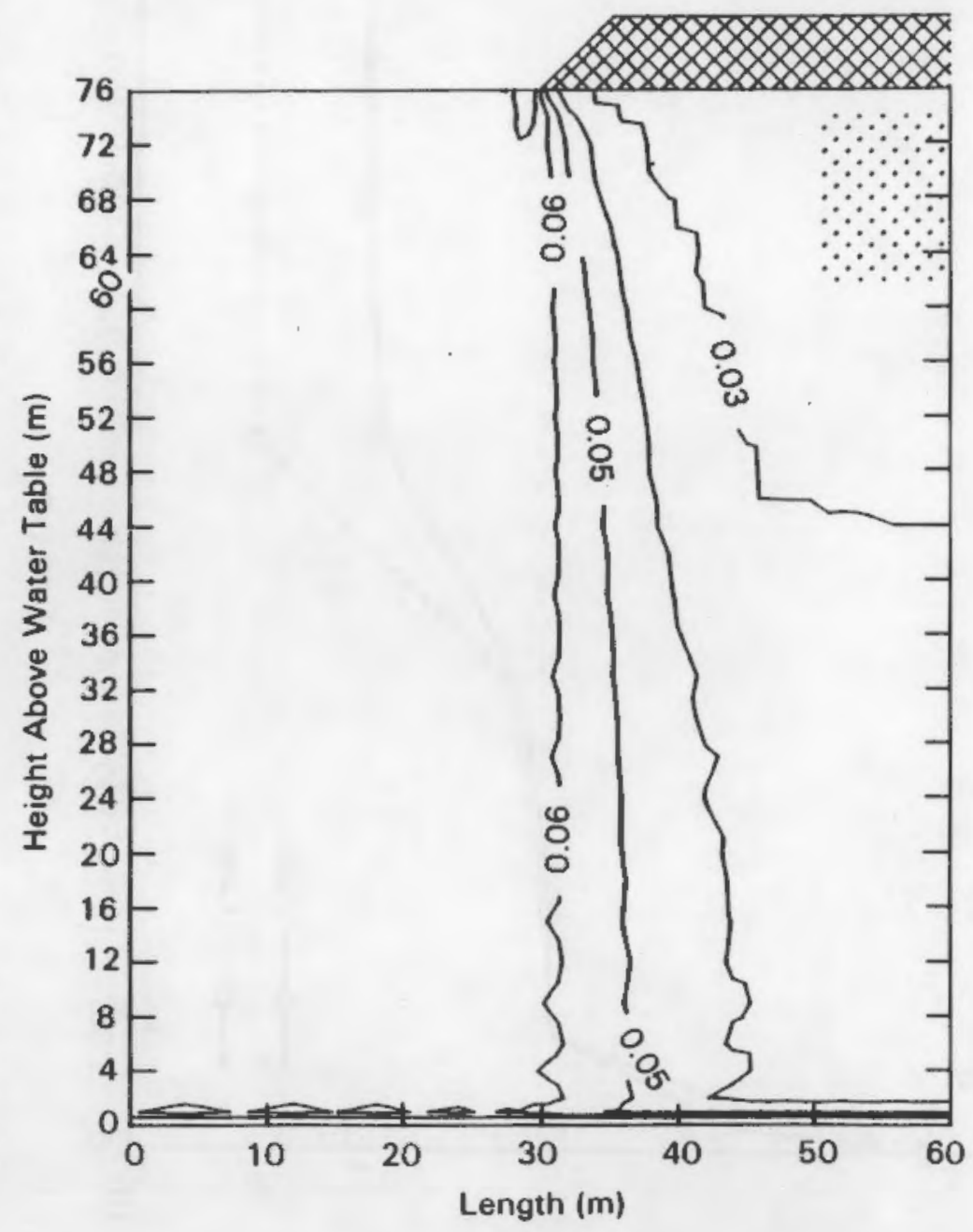

(b)

FIGURE 5.6. Simulated Total Head (a) and Water Content (b) Contours for Case 4, $500 \mathrm{yr}$ 


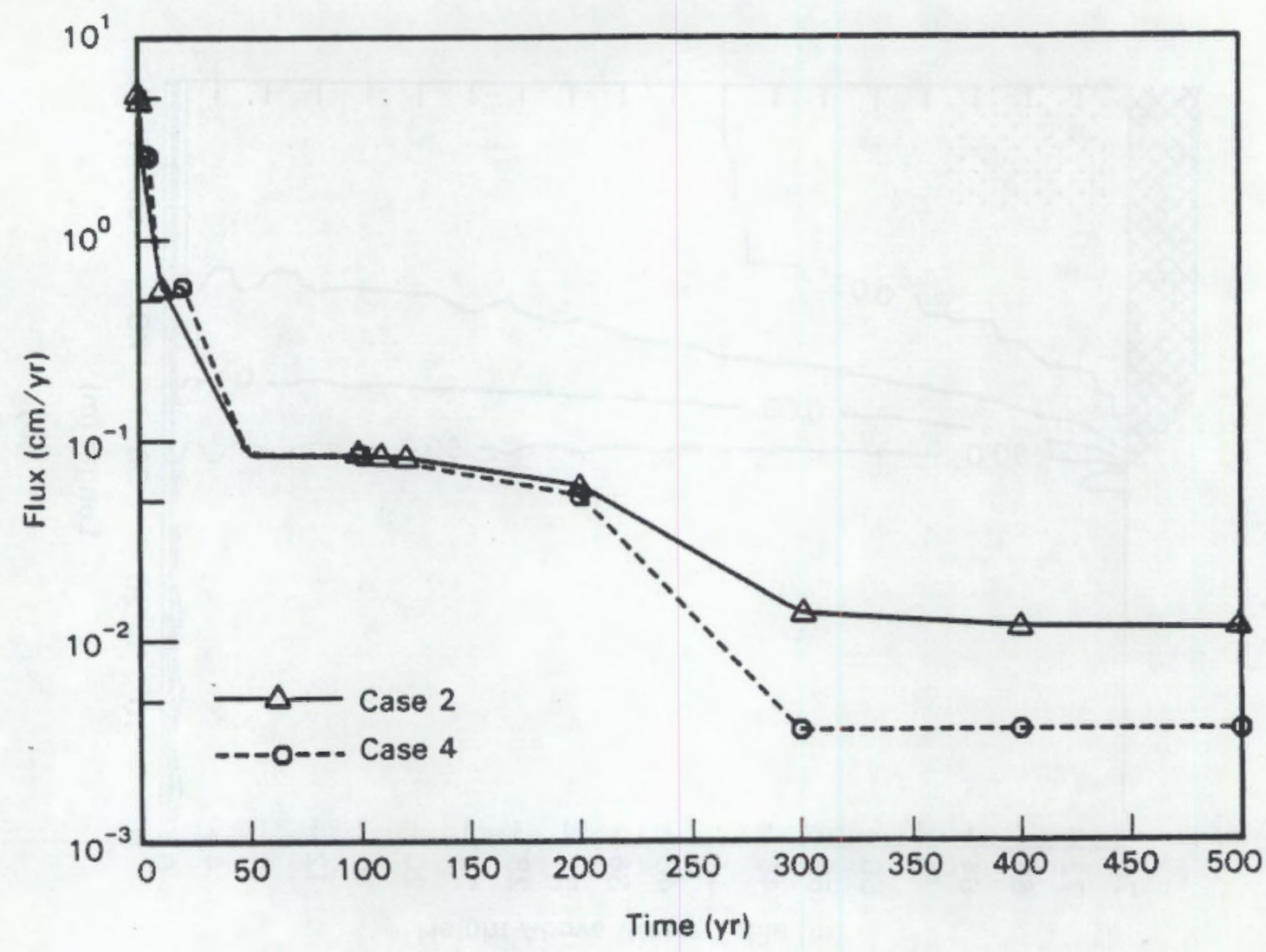

FIGURE 5.7. Estimated Flux Past Bottom-Left Corner of Waste Tank Versus Time for Cases 2 and 4

\subsection{SOIL LAYERING}

Case 5 is identical to Case 2 with two exceptions. The first exception is that a fine-textured material, soil AP6, was placed between the elevations 62 and $64 \mathrm{~m}$, starting from the left side of the simulated area in Figure 4.1 and extending to just beneath the barrier edge. The second exception is that the left side of the simulated area was initialized with the APG soil present while the right side was initialized without the AP6 soil. The two halves were not equilibrated prior to the start of the simulation. The simulation results (total head and moisture content) for case 5 after 500 years are displayed in Figure 5.8 .

The results in Figure 5.8 indicate an area of high moisture content where the APG soil layer is located. This result was expected, given the fine texture of the soil. More important, however, is that the moisture profiles beneath the barrier are not much different than for case 2 at 500 years. 


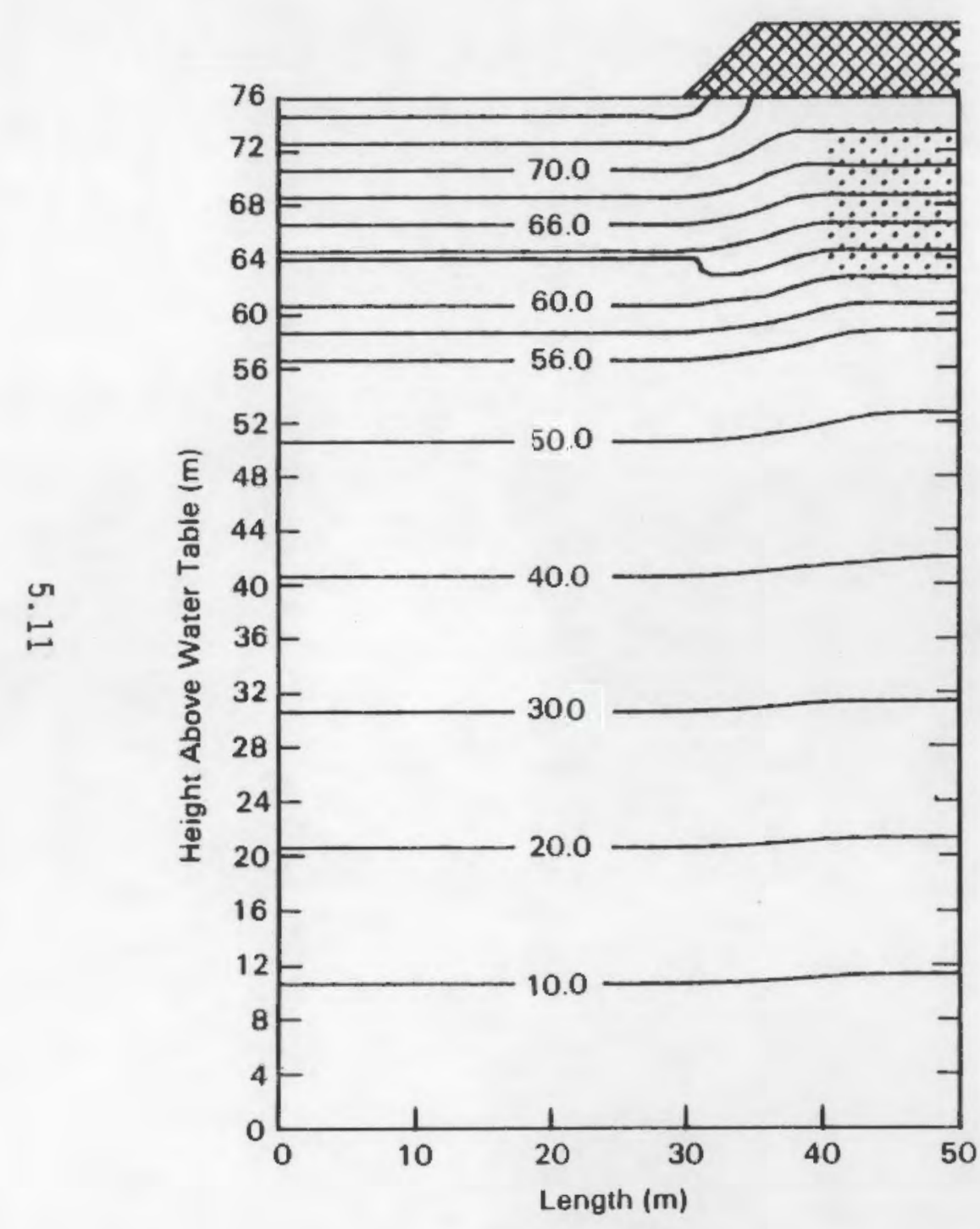

(a)

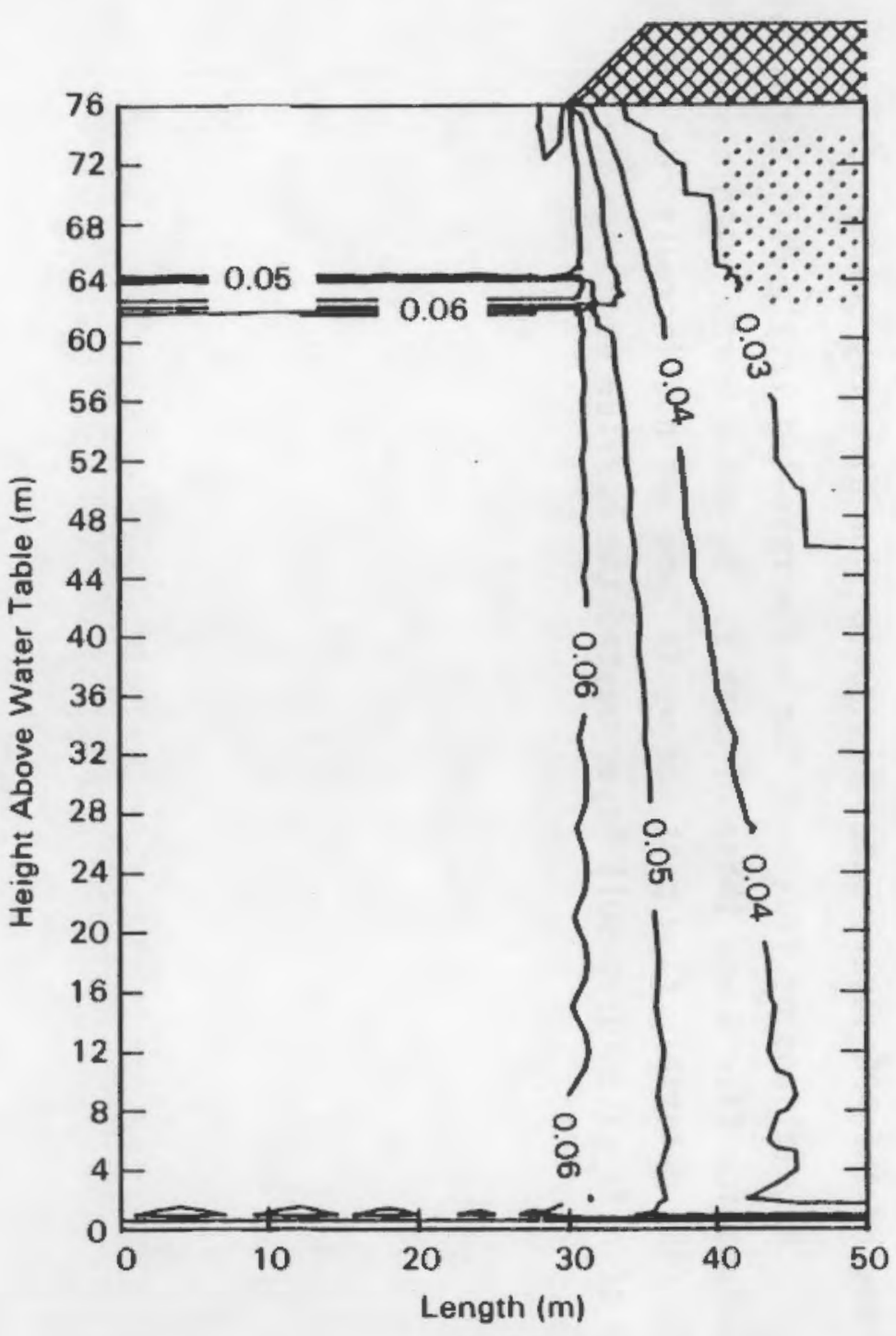

(b)

FIGURE 5.8. Simulated Total Head (a) and Water Content (b) Contours for Case 5, $500 \mathrm{yr}$ 
Although there was some moisture movement around the edge of the AP6 soil layer, it was not significant enough to cause major flow toward the waste. Once beyond the AP6 layer, water tended to flow directly downward.

Calculations of flux past the waste revealed little difference between the values for Case 5 and those of Case 2. In other words, with the AP1 soil as the fill material, flow past the waste tank was not increased by the presence of a fine-textured soil layer beyond the barrier edge. 


\subsection{CONCLUSIONS AND RECOMMENDATIONS}

As with any modeling exercise, the results reported here apply only to the conditions simulated.

\subsection{CONCLUSIONS}

- For an unvegetated barrier, a soil thickness of $150 \mathrm{~cm}$ is not necessarily optimum from a hydrologic point of view. Based on limited simulation results, coarse-textured soils are better (achieve minimum drainage) at shallower thicknesses for a given precipitation regime.

- The lack of an intermediate sand layer between the upper fine soil and the lower gravel layer in the model should not affect comparison work. However, the sand layer may play a role in determining the absolute drainage amount. In such cases, the sand layer should be included in the conceptual model.

- Plant activity can be reduced to the point where drainage begins to occur; therefore, the mere presence of some plants on the barrier does not guarantee barrier performance. For the plant presence to be effective, the community must have a minimum density and biomass, and the root system must penetrate to a minimun depth.

- The use of revised soil hydraulic properties for the RN2 soil indicated that barriers constructed of this material are much better than previously thought. This result illustrates the importance of thoroughly characterizing the hydraulic properties of each material if future barrier performance is to be modeled successfully.

- The use of an "average" annual precipitation distribution yielded lower estimates of drainage compared to estimates made with actual precipitation distribution data. For comparative modeling, this effect may not be critical, but for absolute predictions of drainage the effect is important. When accurate drainage predictions are required, realistic precipitation distributions must be used.

- Below the barrier, soil properties determine the magnitude of the flux past the waste tank and thus play a role in considerations concerning 
how far the barrier edge should be from the tank. For finer-textured material, there is a need for a greater distance between tank and barrier edge.

- For the AP1 soil, the major flux of water past the waste tank occurs during the first 50 years after barrier emplacement and appears to consist almost entirely of in-place water, not water infiltrating from the edge. This type of flow could be reduced by using dry fill material and, once filled, immediately constructing the barrier.

- After only 50 years for the AP1 soil, fluxes past the waste dropped below $0.1 \mathrm{~cm} / \mathrm{yr}$. Water flowing from outside the barrier and past the waste at later times may be so small as to be insignificant when compared to the possible flux coming directly through the barrier. Such a flux may be as high as 0.05 to $0.1 \mathrm{~cm} / \mathrm{yr}$, rates which would dominate the flow regime around the waste tank (given the AP1 soil).

\subsection{RECOMMENDATIONS}

- Devote a major effort to characterizing the hydraulic properties of the barrier materials and the subsurface soils present at the various waste sites.

- Conduct a sensitivity analysis of barrier performance using soil hydraulic conductivity functions generated by different methods.

- Construct a number of possible sequences of annual precipitation distributions for use in assessing long-term barrier performance.

- For the two-dimensional simulation work, devise a method to calculate actual head gradients for any position at any point in time for use in calculating fluxes more accurately.

- Conduct a two-dimensional simulation of an actual single-shell tank farm, using actual dimensions and soil types. 


\subsection{REFERENCES}

Adams, M. R., and N. R. Wing. 1987. Protective Barrier and Warning Marker System Development Plan. RHO-RE-PL-35P, Rockwell Hanford Operations, Richland, Washington.

Bond, F. W., C. R. Cole and P. J. Gutknecht. 1984. Unsaturated Groundwater Flow Model (UNSAT1D) Computer Code Manual. CS-2434-CCH, Electric Power Research Institute, Palo Alto, California.

Brown, D. J. 1960. Geology Underlying 200-Area Tank Farms. HW-67729, General Electric Company, Richland, Washington.

Cline, J. F., D. W. Uresk and W. H. Rickard. 1977. "Comparison of Soil Water Used by a Sagebrush-Bunchgrass and a Cheatgrass Community." Range Manage. 30:199-201.

Davis, L. A., and S. P. Neuman. 1983. Documentation and User's Guide: UNSAT2 - Variably Saturated Flow ModeT. NUREG/CR-3390, Prepared by water, Waste and Land, Inc., Fort Collins, Colorado for the U.S. Nuclear Regulatory Commission, Washington, D.C.

Doorenbos, J., and W. 0. Pruitt. 1977. "Guidelines for Predicting Crop Water Requirements." FAO Irrigation Paper No. 24, 2nd ed., Food and Agricultural Organization of the United Nations, Rome, Italy, pp. 1-107.

Fayer, M. J., W. Conbere, R. R. Heller, and G. W. Gee. 1985. Model Assessment of Protective Barrier Designs. PNL-5604, Pacific Northwest Laboratory, Richland, washington.

Fayer, M. J., G. W. Gee and T. L. Jones. 1986. UNSAT-H Version 1.0:

Unsaturated Flow Code Documentation and Applications for the Hanford Site. PNL-5899, Pacific Northwest Laboratory, Richland, Washington.

Finlayson, B. A., R. W. Nelson and R. G. Baca. 1978. A Preliminary Investigation into the Theory and Techniques of Modeling the Natural Moisture Movement in Unsaturated Sediments. RHO-LD-47, Rockwell Hanford operations, Richland, Washington.

Gee, G. W., and C. S. Simmons. 1979. Characterization of the Hanford 300 Area 8urial Grounds. Task III - Fluid Transport and Modeling. PNL-2921, Pacific Northwest Laboratory, Richland, Washington.

Harris, G. A. 1967. "Some Competitive Relationships Between Agropyron Spicatum and Bromus Tectorum." Ecological Monogr. 37(2):89-111.

Hinds, W. T. 1975. "Energy and Carbon Balances in Cheatgrass: An Essay in Autecology." Ecological Monogr. 45:367-388.

Klemmedson, J. 0., and J. G. Smith. 1964. "Cheatgrass (Bromus Tectorum L.)." Bot. Rev. 30:226-262. 
Last, G. V., and M. C. Marratt. 1978a. Generalized Geology of the 241-AW Tank Farm. RHO-LD-31, Rockwell Hanford Operations, Richland, Washington.

Last, G. V., and M. C. Marratt. 1978b. Generalized Geology of the 241-AN Tank Farm. RHO-LD-32, Rockwell Hanford Operations, Richland, Washington.

Lu, A. H., S. J. Phillips and M. R. Adams. 1982. "Fjnite Element Model Evaluation of Barrier Configurations To Reduce Infiltration Into Waste Disposal Structures: Preliminary Results and Design Considerations." Presented at the Proceedings of the Symposium on Waste Management, March 8-11, 1982, Tucson, Arizona.

Stone, W. A., J. M. Thorp, 0. P. Gifford, and D. J. Hoitink. 1983. Climatological Summary for the Hanford Area. PNL-4622, Pacific Northwest Laboratory, Richland, Washington.

Sauer, R. H., M. L. Warner and W. T. Hinds. 1984. "Indirect Determination of Rooting Depth and Permanent Wilting Point." Ecological Model. $21: 109-124$.

Vomocil, J. A. 1965. "Porosity." In Methods of Soil Analysis, Part 1 , ed. C. A. Black, pp. 299-314. American Society of Agronomy, Madison, Wisconsin.

U.S. Department of Energy. 1986. Draft Environmental Impact Statement, Disposal of Hanford Defense High-Level, Transuranic and Tank Wastes, Hanford Site, Richland, Washington. DoE/EIS-0113 (Vol. 3), U.S. Department of Energy, Washington, D.C. 


\section{DISTRIBUTION}

No. of

Copies

OFFSITE

M. J. Barainca, Program Manager

Low-Leve] Waste Management

Program

Idaho Operations Office

U.S. Department of Energy

550 Second Street

Idaho Falls, ID 83401

R. Boland

Waste Management Project Office

Nevada Operations Office

U.S. Department of Energy

P.0. Box 14100

Las Vegas, NV 89114

G. S. Campbel1

Washington State University

Pullman, WA 99164

T. C. Chee

R\&D and Byproducts Division

DP-123 (GTN)

U.S. Department of Energy

Washington, DC 20545

B. W. Church, Director

Health Physics Division

Nevada Operations Office

U.S. Department of Energy

P.0. Box 14100

Las Vegas, NV 89114

F. Gorup, Program Manager

Nuclear Waste Management Group

Chicago Operations Office

U.S. Department of Energy

9800 South Cass AVenue

Argonne, IL 60439

J. J. Jicha, Director

R\&D and Byproducts Division

DP-123 (GTN)

U.S. Department of Energy

Washington, DC 20545
No. of

Copies

0. D. Markham

U.S. Department of Energy

Idaho Operations office

Radiological and Environmental

Sciences Laboratory

Idaho Falls, ID 83401

D. B. Leclaire, Director

Office of Defense Waste and

Byproducts Management

DP-12 (GTN)

U.S. Department of Energy

Washington, DC 20545

M. H. McFadden

TRU Waste Program Manager

Waste Management and Transportation Development Division

U.S. Department of Energy

P.0. Box 5400

Albuquerque, NM 87115

R. L. Watters

Ecological Research Division

ER-75

Office of Health and Environmental Research, OER

U.S. Department of Energy

Washington, DC 20545

30 DOE Technical Information Center

Technical Library

Argonne National Laboratory

Argonne, IL 60439

Peter Colombo, Group Leader

Nuclear Waste Research

Brookhaven National Laboratory

Building 701

Upton, NY 11973 
No. of

Copies

E. A. Jennrich

Low-Level Management Program

EG\&G Idaho, Inc.

P.0. Box 1625

Idaho Falls, ID 83415

Environmental Protection Agency

Technology Assessment Division

Office of Radiation Programs

Washington, DC 20460

Technical Library

Idaho National Engineering Laboratory

Idaho Falls, ID 83401

Technical Library

Los Alamos National Laboratory

Los Alamos, NM 87545

T. E. Hakonson

Los Alamos National Laboratory

Los Alamos, NM 87545

J. W. Nyhan

Los Alamos National Laboratory

P.0. Box 1663

Los Alamos, NM 87545

National Academy of Sciences

National Research Council

2101 Constitution Avenue

Washington, DC 20418

P. J. Wierenga

Department of Soil Science

New Mexico State University

Las Cruces, NM 88004

Dan Stephens

Department of Geosciences

New Mexico Institute of Mining and Technology

Socorro, NM 87801
No. of

Copies

Technical Library

Oak Ridge National Laboratory

Oak Ridge, TN 37830

E. W. Kendal1

Waste Management Project Manager REECO

P.0. Box 642

Mercury, NV 89023

J. J. Blakeslee, Program Manager

Nuclear Waste Processing

Rockwell International

P.0. Box 464

Golden, CO 80401

C. E. Wickland

Manager, Waste Operations

Rockwell International

Rocky Flats Plant

P.0. Box 464

Golden, CO 80401

J. C. Corey

Savannah River Laboratory

P.0. Box A

Aiken, SC 29801

I. W. Marine

Savannah River National Laboratory

Box A

Aiken, SC 29801

Technical Library

Savannah River Nationa?

Laboratory

Aiken, SC 29081

A. W. Warrick

Department of Soils, Water, and Engineering

University of Arizona

Tucson, AZ 85721 
No. of

Copies

E. M. Romney

University of California

of Los Angeles

Westwood, CA 96137

D. Hillel

12A Stockbridge Hall

University of Massachusetts

Amherst, MA 01003

W. A. Jury

Department of Soils

University of California

at Riverside

Riverside, CA 92502

Jack Fischer

Low-Level Radioactive Waste Program

U.S. Geological Survey

Water Resources Division

12201 Sunrise Valley Drive

Reston, VA 22091

I. J. Winograd

U.S. Geological Survey

National Center - Mail Stop 432

Reston, VA 22092

E. P. Weeks

U.S. Geological Survey

Federal Center Mail Stop 413

Denver, CO 80225

E. O'Donnell

Earth Sciences Branch

Division of Health, Siting and Waste Management Research

U.S. Nuclear Regulatory Commission

Washington, DC 20555

T. J. Nicholson

Division Health, Siting and Waste Management

U.S. Nuclear Regulatory Commission

MS 1130 SS

Washington, DC 20555
No. of

Copies

G. S. Campbell

Washington State University

Pullman, WA 99164

Jeanne Rense]

$\mathrm{Hi}$-Level Waste Management

Washington State Department of Ecology - Pu II

Olympia, WA 98504

Scott $W$. Tyler

Desert Research Institute

P.0. Box 60220

Reno, NV 89506

ONSITE

8 DOE Richland Operations Office

E. A. Bracken

R. A. Holten

J. R. Hunter

N. T. Karagianes

G. W. Rosenwald

J. J. Sutey

J. D. White

J. K. W. Wukelic

21 Westinghouse Hanford Company

M. R. Adams

S. Baker

L. C. Brown

R. A. Carlson

W. H. Chapman-Riggsbee

C. Defigh-Price

C. J. Geier

W. F. Heine

W. A. Jordan

R. E. Lerch

G. G. Meade

S. J. Phillips

J. F. Relyea

R. C. Routson

P. S. Schaus

W. W. Schulz

S. A. Wiegman

G. F. Williamson

N. R. Wing 
No. of

Copies

R. D. Wojtasek

D. E. Wood

2 UNC Nuclear Industries

K. A. Gano

D. R. Pratt

51 Pacific Northwest Laboratory

P. A. Beedlow

P. E. Bramson

J. W. Cary

W. Conbere

D. W. Dragnich

M. J. Fayer (15)

G. W. Gee (5)

M. J. Graham
No. of

Copies

H. A. Haerer

J. K. Hales

M. S. Hanson

P. C. Hays

$P$. R. Heller

$T$. L. Jones

C. T. Kincaid

R. R. Kirkham

G. V. Last

A. E. Reisenauer

L. E. Rogers

R. L. Skaggs

R. J. Serne

C. S. Simmons

J. A. Stottlemyre

G. P. Streile

S. G. Weiss

R. E. Wildung

Publishing Coordination (2)

Technical Report Files (5) 